\title{
UNION DEMOCRACY AND FAIR REPRESENTATION: FEDERAL RESPONSIBILITY IN A FEDERAL SYSTEM
}

\section{HARRY H. WELLINGTONं}

"[T]HIs committee expects to give attention to problems inherent in labormanagement collusion, underworld infiltration of the labor movement, misuse of union and welfare funds, suppression of civil rights and liberties of union members by their leaders, conflict of interest, and the use of violence, shakedowns, and extortions."' These great expectations were pronounced by Senator McClellan, Chairman of the Senate Select Committee on Improper Activities in the Labor or Management Field, at that body's first public meeting. Their realization is spread upon the now vast record of his committee. ${ }^{2}$ This record -perhaps "exposé" is more appropriate-has prompted legislators to suggest federal regulation in three broad areas : $:^{3}$ protection of the beneficiary's interest in employee pension, health and welfare funds; ${ }^{4}$ protection of the individual member's interest in union treasuries ${ }^{5}$ and protection of the employee's

†Associate Professor, Yale Law School.

1. Hcarings Before the Select Committee of the Senate on Improper Activities in the Labor or Management Field, 85th Cong., 1st Sess., pt. 1, at 2 (1957).

2. The hearings were begun on February 26,1957 , and were still in full swing in the summer of 1958. As of April 1, 1958, the record contained 10,384 pages. See Hearings, supra note 1, at pt. 26. The committee submitted its first interim report in April 1958. See Senate Select Comimittee on Improper Activities in the Labor or Management Fiedo, INTERIM REPORT (March 1958).

3. The Select Committee itself made legislative recommendations in five areas: (1) pension, health and welfare funds; (2) union funds; (3) union democracy; (4) middleman in labor-management disputes; and (5) federal pre-emption in labor relations. Id. at 450-51. The last of these problems is extraneous to the Committee's work. Most of the proposed legislation seems to fit more easily into the classifications suggested in text. See notes 4-6, 9 infra.

4. The Senate Select Committee was but one of several congressional committees to inquire-and this was not central to its purpose-into the pension-welfare fund problem. See S. REP. No. 1734, 84th Cong., 2d Sess. (1956) ; Hearings Before the Subcommittee on Welfare and Pension Plans Legislation of the Senate Committee on Labor and Public Welfare, 85th Cong., 1st Sess. (1957). The issues in this area are examined in Note, Protection of Beneficiaries Under Employee Benefit Plans, 58 CoLur. L. REv. 78 (1958).

The Senate has passed the Pension and Welfare Fund Disclosure Bill, S. 2888, 85th Cong., 2d Sess. (1958). See 104 Cong. REc. 6778 (daily ed. April 28, 1958).

5. See, e.g., S. 3974, 85th Cong., 2 d Sess., tit. 1 (1958) (Kennedy-Ives. Senator Kennedy's first labor bill was S. 3454 , 85th Cong., 2d Sess. (1958)). S. 3974 was favorably 
interest in the fidelity of union officials who bargain with employers. ${ }^{6}$ Except in the realm of the union-trusteeship-a device for international union control of the local-congressional investigation has not disclosed the employee's stake in democratic union government to be a fourth area of needed legislation. ${ }^{7}$

Past studies of unions, however, do suggest such a need. ${ }^{8}$ Moreover, increased interest in all aspects of internal union affairs following the committee's much-publicized hearings has stimulated discussion about the advisability of statutory regulation of union admissions, expulsions, elections and international-local relations, ${ }^{9}$ that is, of those activities clearly vital to successful union democracy. Indeed, legislation, avowedly to promote such democracy, has recently been introduced in Congress. ${ }^{10}$ This Article is concerned with federal regulation of the first three subjects. ${ }^{11}$ Before reaching admissions,

reported out of committee, see S. REp. No. 1684, 85th Cong., 2d Sess. (1958), and passed the Senate in amended form, 104 CoNg. REc. 10381 (daily ed. June 17, 1958). See also S. 3097, 85th Cong., 2d Sess., tit. 1, 2 (1958) (Administration bill).

6. See, e.g., S. 3974, 85th Cong., 2d Sess., tit. 1, $\$ 102$ (1958); S. 3097, 85th Cong., 2d Sess. § 103 (1958).

7. Hearings, supra note 1 .

8. See Amirrican Civil Liberties Union, Denocracy in Trade Unrons (1943); Aaron \& Komaroff, Statutory Regulation of Internal Union Affairs, 44 ILL. L. REv. 425, 631 (1949) ; Kovner, The Legal Protection of Civil Liberties Within Unions, 1948 WIs. L. Rev. 18; Summers, The Right To Join a Union, 47 ColuM. L. Rev. 33 (1947) ; Summers, Legal Limitations on Union Discipline, 64 Harv. L. Rev. 1049 (1951); Summers, Disciplinary Powers of Unions, 3 Ind. \& LAB. ReL. Rev. 483 (1950); Summers, Union Powers and Workers' Rights, 49 MrcH. L. Rev. 805 (1951) ; Summers, Union Democracy and Union Discipline, N.Y.U. 5TH CONF. oN LAB. 443 (1952); Summers, Admission Policies of Labor Unions, 61 Q.J. Econ. 66 (1946); Taft, Democracy in Trade Unions, 36 Am. Econ. Rev. 359 (Supp. 1946) ; Taft, The Constitutional Pozerer of the Chief Officer in American Labor Unions, 62 Q.J. EcoN. 459 (1948); Taft, Judicial Procedure in Labor Unions, 59 Q.J. EcoN. 370 (1945).

9. Cox, The Role of Law in Preserving Union Denocracy (unpublished paper; copy on file in Yale Law School Library 1958); SeIDman, Democracy in the Labor Movement (N.Y. State School of Ind. \& Lab. Rel. Bull. No. 39, 1958) ; Barbash, Union Democracy, in Subcommittee on Labor of the Senate Committee on Labor and Public Welfare, Selected Readings on Government Regulation of Internal Union Affairs Affecting the Rights of Members, 85th Cong., 2d Sess. 132 (1958) (hereinafter cited as SELECTED ReAdrNcs) ; Kerr, Unions and Union Leaders of Their Own Choosing, in Selected READINGS 106; Summers, Legislating Union Democracy, in id. at 250.

10. The current session of Congress has considered several bills. See, e.g., S. 3974, 85th Cong., 2d Sess. (1958), discussed note 5 supra (concerning elections and trusteeship) ; S. 3097, 85th Cong., 2d Sess. (1958) (elections); S. 3069, 85th Cong., 2d Sess. (1958) (elections, discipline, trusteeships).

11. International-local relations pose discrete questions which will not be discussed. Nonetheless, trusteeships-the most troublesome aspect of international-local union relations-may affect the individual as extensively as admission, discipline and election policy. Federal interest in the latter areas may be greater, however, because admission, discipline and election policies more directly impinge upon the individual. The multistate character of trusteeships would nevertheless seem to overweigh this consideration. In any event, the additional complexities attending the trusteeship problem make its treatment in this Article undesirable. 
expulsions and elections proper, however, the Article will treat some preliminary issues, unrelated to the partisan political considerations involved in enacting labor legislation, but relevant to ultimate evaluation of the federal government's proper role in protecting union democracy. ${ }^{12}$

First, perhaps, "union democracy" should be defined, and then some assumptions made. Clyde Summers' definition is especially apt. "Union democracy," he says, "means, first, full freedom of dissent, of criticism, and of opposition. Union democracy requires, second, that decisions shall be made and executed on the basis of the members' expressed desires-the right to choose, even unwisely. Self-government is self-fulfillment. Third, recognition of personal worth requires recognition of the equality of men-the right to fair and equal treatment. Minorities must not be trampled upon by assertive majorities. Finally, every person is entitled to be judged only after full and fair hearings before tribunals that have no personal or institutional stake other than the search for justice."13 This is more than a definition. In a declarative fashion, Summers' words establish a prima facie case for democratic union government. They also suggest why protection of the employee's interest in admission, discipline and election is so important to achievement of union democracy. Full admission of all employees represented by a union is crucial because it is the condition precedent to full participation by the group most directly interested in union decisions. Protection from arbitrary invocation of discipline permits opposition. And the ballot in a free election is the individual union member's weapon for inducing performance in accordance with his desire.

But open admission, fair discipline and free elections do not make union democracy. ${ }^{14}$ Apathy-to mention only the most destructive factor-can nullify

12. The "political" considerations which therefore will be examined concern "the conduct of government, referring in the widest application to the judicial, executive, and legislative branches . ..." 3 Webster, New International Dictionary 1909 (2d unabridged ed. 1957).

13. Summers, Democracy in Trade Unions, The New Leader, Feb. 10, 1958, p. 7.

14. Probably the most instructive book on union democracy and the conditions necessary for its existence is LrPser, Trow \& Colenran, Union Denrocracy (1956). See, particularly, id. at 393-418.

Clyde Summers has suggested that the following additional requirements are necessary for "functioning democracy" at the international level: "First, democracy requires available channels of communication to make possible interchange of ideas, distribution of information, and organization of protest. Second, democracy must provide opportunities for the training of leaders who gain the skills and status to provide effective leadership to the opposition. Third, democracy is severely handicapped if there is a monolithic bureaucracy of officers and staff employees who hold their positions subject to the will of those in power. Protest from those best informed and able to lead is silenced, and any opposition is overwhelmed by the disciplined machine. Fourth, the three elements above suggest the critical value of local autonomy. The local newspaper may provide a counterbalance to the national publication; the local may have funds and facilities to make protests known throughout the union; it can provide independent leaders and an independent bureaucracy. This same value may be served by district, regional or departmental structures to the extent that they are independent of central control." Summers, The Usefulness of Laze in Achieving Union Democracy, 48 Am. Econ. Rev. 44, 46 (Supp. 1958). 
these requisites..$^{15}$ Admission, discipline and election, however, are not only areas of primary importance to union democracy, they are areas susceptible to effective legislation. ${ }^{16}$

Democracy in unions is worth having, as the Summers definition indicates. Most people, including most union people, agree, ${ }^{17}$ although some observers seem to question its importance. ${ }^{18}$ Their skepticism is grounded in a suspicion that undemocratic unions are likely to be more responsible to the community than democratic ones, or that nonresponsible union officers are as likely to know labor's best interests as directly responsible ones. ${ }^{10}$ Both of these theories are usually-and quite properly-advanced tentatively. As reflections of empirical data, they lack evidentiary support; as naked assertions, persuasiveness. ${ }^{20}$ This Article will assume, therefore, that democratic labor unions are desirable-the author has been conditioned so to believe without requiring an overwhelming demonstration of democracy's superiority.

Such a belief in democratic union government and the realization that unions are not always democratic may be enough, for some, to justify federal legislation. Particularly so, if the belief and the realization are coupled with an assurance that labor unions are different from private social clubs. Today, this assurance may be ventured without the presentation of evidence, for labor unions notoriously exercise enormous economic power. It is also obvious that this power far exceeds that of any other "club," save, perhaps, the United States Senate. Connection between end and means is thus easily made: unions should be democratic. The federal government should be concerned with

15. "[D] emocracy is achieved if the members can make their will felt, if they can replace the leaders and change the policies that they dislike. Their ability to do this, however, is diminished by the low level of membership participation found in most local unions." Seidman, Requirements for Union Democracy, S1 Monthly LaB. Rev. 255 (1958). See Code VI, Union Democratic Processes, in AFL-CIO Codes of Ethical Practices 41, 42 (1957). For a study of apathy and its effect in a British labor union, see Goldstein, The Governanent of a Britrsh Trade Union (1952).

16. "The law could not, if it would, decree union democracy, for apathetic members cannot be compelled to action, nor can indifference be transformed to interest. The most that the law can do is to safeguard the basic rights essential for the life of union democracy and to contribute where possible to encouraging those institutions which give it vitality." Summers, The Usefulness of Law in Achieving Union Democracy, 48 Anr. Econ. REv. 44, 52 (Supp. 1958).

17. "The entire labor movement in the United States and in all free countries in the world is based upon the democratic tradition. Freedom and democracy are the essential attributes of our labor movement. Labor organizations lacking these attributes, like Hitler's Labor Front, Franco's syndicates and Moscow's captive unions, are unions in name only." Goldberg, The Rights and Responsibilities of Union Members, 9 LAB. L.J. 298, 299 (1958). See AFL-CIO Constiturion art. II, \$ 10; see also Code VI, Union Democratic Processes, in AFL-CIO Codes of Ethical Practices 41 (1957).

18. See Allen, Power in Trade Unions 10-15 (1954) ; Dunlop, The Public Interest in Intemal Affairs of Unions, 1957 A.B.A. Section of LAB. ReL. LAw 10; Jacobs, Union Democracy and the Public Good, Commentary, Jan. 1958, p. 68.

19. See authorities cited note 18 supra.

20. See, generally, Lipset, Trow \& Colemar, Union Dearocracy 403-412 (1956). 
private groups which possess very great power. This second proposition is also beyond debate. Since some unions are not democratic, but all unions are powerful, the federal government, so the syllogism goes, must see that all unions become democratic.

But this easily assumed conclusion that "there 'oughtta' be a law" stamped "made in Washington," should properly be tested by an analysis of the complex body of federal and state regulation already touching on labor unions. Some of this regulation must be understood in principle, if not in detail, before a decision to alter the status quo is made. Such an understanding is essential to an appreciation of the present distribution of power and responsibility among federal government, state governments and private groups. And this distribution must be of central concern whenever federal legislation in a new area of activity is proposed. ${ }^{21}$

\section{Federal Labor Law and the Duty of the Federal Governaient}

Collective bargaining is the central process of industrial relations in this country, a method of private ordering on a grand scale. Its product, the collective agreement, is a code, not a contract. Because this private arrangement so widely affects the public, one of the principal purposes of federal labor regulation is to shield the bargaining process from private or state interference. ${ }^{22}$

The Railway Labor Act and the National Labor Relations Act, by sanctioning the combination of employees, ensure the roughly equivalent labor-management power distribution which a national program of collective bargaining pre-

21. Before federal power is invoked, some limitations on legislating for an enlightened union society should also be understood. A specific statutory provision designed to force democracy upon union members would surely fail to accomplish its purpose. Rather, legislators would be wise to support a statute designed to encourage democracy in unions. To use a crude example, instead of favoring legislation which would compel members to attend union meetings, the legislator would be well advised to advocate statutory protection for the union member who participated in an unpopular cause. Cf. note 16 supra.

With the exception of the tangential regulation described in the section of this Article entitled Federal Labor LaW and the DUty of the FEDERAL Government, at the time of writing, no federal legislation had been enacted dealing with union democracy. S. 3974, S5th Cong., 2d Sess. (1958), discussed notes 5, 10 supra, which passed the Senate on June 17,1958 , was before the House where it was expected to die. See N.Y. Times, June 19, 1958, p. 1, col. 5. Although the bill was passed 88 to 1 by the Senate, see 104 Cong. Rec. 10381 (daily ed. June 17, 1958), no discussion of the problems examined in this Article seems to have been raised before that body.

22. National Labor Relations Act $\$ 8,61$ Stat. 140 (1947), as amended, 29 U.S.C. $\$ 158$ (1952), proscribes, inter alia, certain employer and union practices which are inimical to collective bargaining. Section 2 of the Railway Labor Act, 44 STAr. 577 (1926), as amended, 45 U.S.C. $\$ 152$ (1952), is the pertinent provision of that statute. These acts do not expressly prohibit state interference with national policy, but case law makes very clear what is implicit in the statute. See, e.g., Guss v. Utah Labor Relations Bd., 353 U.S. 1 (1957) ; Garner v. Local 776, Teamsters Union, AFL, 346 U.S. 485 (1953); Hill v. Florida $e x \mathrm{rel}$. Watson, 325 U.S. 538 (1945). See also Cox, Federalism in the Law of Labor Relations, 67 HARv. L. REv. 1297 (1954). 
supposes. ${ }^{23}$ The second prerequisite of effective bargaining is also accomplished by statute-investing the union of a majority of the employees in an appropriate unit with the right to represent all employees in that unit, and requiring the employer to bargain in good faith with this union about wages, hours and conditions of employment. ${ }^{24}$ In J. I. Case Co. v. NLRB, ${ }^{25}$ the Supreme Court gave direction to this obligation in a decision with far-reaching implications for the problems discussed in this Article. The J. I. Case Company had entered into individual contracts of employment with seventy-five per cent of its labor force prior to National Labor Relations Board certification of a $\mathrm{CIO}$ union as employee bargaining representative. The individual contracts were of a year's duration, provided for pay at a specified rate and for other company benefits, and imposed duties of faithfulness, honesty and responsibility for improper work on each contracting employee. After NLRB certification, the union "asked the Company to bargain. It refused [as to matters covered by the employee agreements], declaring that it could not deal with the union in any manner affecting rights and obligations under the individual contracts ...."26 The Board held this refusal an unfair labor practice, and the Supreme Court agreed.

"Individual contracts, no matter what the circumstances that justify their execution or what their terms, may not be availed of to defeat or delay the procedures prescribed by the National Labor Relations Act looking to collective bargaining, nor to exclude the contracting employee from a duly ascertained bargaining tunit; nor may they be used to forestall bargaining or to limit or condition the terms of the collective agreement. ... Wherever private contracts conflict with its functions, they obviously must yield or the Act would be reduced to a futility."27

This decision is sound. It is solidly grounded in the language of the National Labor Relations Act ${ }^{28}$ and in that statute's legislative history.20 Perhaps only

23. National Labor Relations Act $\$ 7,61$ STAT. 140 (1947), 29 U.S.C. $\$ 157$ (1952); Railway Labor Act $\S 2$ (Fourth), 44 STAT. 577 (1926), as amended, 45 U.S.C. $\$ 152$ (Fourth) (1952).

24. National Labor Relations Act $\S 8$ (a) (5), 61 Star. 141 (1947), as amended, 29 U.S.C \$ 158(a) (5) (1952); Railway Labor Act § 2, 44 STAT. 577 (1926), as amended, 45 U.S.C. $\$ 152$ (1952). See 61 STAT. 143 (1947), as amended, 45 U.S.C. $\$ 159$ (a) (1952): "Representatives designated or selected for the purposes of collective bargaining by the majority of the employees in a unit appropriate for such purposes, shall be the exclusive representatives of all the employees in such unit for the purposes of collective bargaining ..." See also 61 Stat. 141, 142 (1947), as amended, 29 U.S.C. $\$ \$ 158$ (b) (3) (requiring good faith bargaining by the union), 158(d) (defining good faith bargaining) (1952).

25. 321 U.S. 332 (1944).

26. Id. at 334 .

27. Id. at 337 .

28. 61 StAT. 143 (1947), as amended, 45 U.S.C. $\$ 159$ (a) (1952), quoted note 24 supra. Cf. Order of Railroad Telegraphers v. Railway Express Agency, Inc., 321 U.S. 342 (1944) (applying the majority-rule principle of Case to industries regulated by the Railway Labor Act).

29. The relevant legisiative history is reviewed with care and accuracy in Weyand, Majority Rule in Collective Bargaining, 45 Colum. L. REv. 556 (1945). 
Mr. Justice Roberts, who alone dissented, seriously questioned the Court's opinion. ${ }^{30}$ The decision is nevertheless far-reaching.

Several factors which might be thought relevant to the judgment in the case are quite irrelevant. It makes no difference, for example, whether an individual is able to do better bargaining on his own than under the collective agreement ${ }^{31}$ or whether his own contract is negotiated before or after the union is certified. ${ }^{32}$ Most important, it is immaterial whether the separate contract is with an employee who does not want to be represented by the majority union. ${ }^{33}$ This means that in the collective bargaining processor at least during negotiation of the collective agreement-an employee, even against his wishes, is represented by the majority union. After voting against the union, a dissenting employee who remains in dissent or is denied membership in the majority union, has no say about his wages, hours and working conditions. The law of his job is determined by his employer and another man's union.

Collective bargaining might work in this country without the Case principle of majority rule. It does elsewhere. ${ }^{34}$ But the principle has much to be said for it, as Mr. Justice Jackson observed in his celebrated Case opinion:

"[T] he individual contract cannot be effective as a waiver of any benefit to which the employee otherwise would be entitled under the trade agreement. The very purpose of providing by statute for the collective agreement is to supersede the terms of separate agreements of employees with terms which reflect the strength and bargaining power and serve the welfare of the group. ..."

".... [A]dvantages to individuals may prove as disruptive of industrial peace as disadvantages. They are a fruitful way of interfering with organization and choice of representatives; increased compensation if individually deserved, is often earned at the cost of breaking down some other standard thought to be for the welfare of the group, and always creates the suspicion of being paid at the long-range expense of the group as a whole." 35

The majority-rule concept is today unquestionably at the center of our federal labor policy.

Prior to the federal statutes, a dissenting employee could represent himself unless the majority union, without the benefit of federal protection against

30. 321. U.S. at 342 (dissent registered without opinion).

31. Id. at 338-39.

32. Order of Railroad Telegraphers v. Railway Express Agency, Inc., 321 U.S. 342 (1944).

33. In addition to Case, see Steele v. Louisville \& N.R.R., 323 U.S. 192 (1944); Order of Railroad Telegraphers v. Railway Express Agency, Inc., supra note 32; Medo Photo Supply Corp. v. NLRB, 321 U.S. 678 (1944).

34. See, e.g., Teller, British Versus American Labor Laws and Practices: A Study in Contrasts, 1957 A.B.A. Section of LAB. ReL. LAw 19; Kahn-Freund, English Labor Law and Collective Bargaining, 1957 id. at 42, 44. See, generally, ConTEMPORARY CoLlective Bargaining in Seven Countries (Sturmthal ed. 1957).

35. 321. U.S. at $338-39$. 
employer and state interference, had sufficient economic power to extract a union-shop agreement from his employer. This right of self-representation may not in itself have been very valuable-one worker had little leverage. If in a given situation, however, there was more than one dissenting worker, combination and independent representation were legally open to this minority group. But whether the right of self-representation was worth much or not, its replacement by the majority-rule principle of federal law and that same law's protection of the union from employer and state interference combine to impose a substantial obligation upon the federal government.

Unlike an employer, who usually has no reason to discriminate against a minority employee, the majority union may have several reasons. ${ }^{36}$ Two are apparent: the dissenter is a threat to the power position of the union; ${ }^{37}$ the dissenter is a participant in labor's share of the gross returns. Less for the nonunion man may mean more for union men. ${ }^{38}$ Whether this is actually the case in every situation is irrelevant, for an apparent conflict of interest always exists. It would be intolerable under these circumstances if the union of the majority, empowered and protected by federal law, were free to disregard the interests of the minority. Indeed, Supreme Court opinions suggest that a statute investing a labor organization with the right to represent all employees would be unconstitutional if it did not impose a duty upon the chosen organization to represent all employees fairly. ${ }^{39}$

This constitutional question has not been decided because the federal statutes have been read to require fair representation. Although the obligation is not explicit in either the Railway Labor Act or the National Labor Relations Act, in a series of wise and not unorthodox opinions beginning with Steele $v$. Louisville \& N.R.R., ${ }^{40}$ the Supreme Court has interpreted both statutes to avoid the potential constitutional difficulty. ${ }^{41}$ In Steele, petitioner-a Negro fireman whom union rules barred from membership-was employed by the railroad. The Brotherhood of Locomotive Firemen and Enginemen, the exclusive bargaining representative of the carrier's white and Negro firemen, had a collective agreement with the railroad which discriminated against Steele and the other Negroes in the unit, because they were Negroes, in matters of seniority and promotion. Steele, both in his own behalf and in a representative capacity,

36. In some cases, of course, the employer's desire for peaceful relations with the union could lead to employer discrimination against the minority (anti-union) employee.

37. Cf. Wallace Corp. v. NLRB, 323 U.S. 248 (1944).

38. To those who may deny that this is true in the long run, Lord Keynes's quip that, in the long run we will all be dead is, I think, an adequate answer.

39. Compare Railway Employees' Dep't, AFL v. Hanson, 351 U.S. 225, 232 (1956), with Steele v. Louisville \& N.R.R., 323 U.S. 192, 198-99 (1944); id. at 208 (concurring opinion of Mr. Justice Murphy).

40. 323 U.S. 192 (1944).

41. The duty of fair representation has been found in the Railway Labor Act $\S 2$ (Fourth), 44 Stat. 578 (1926), as amended, 45 U.S.C. $\S 152$ (Fourth) (1952), and in the National Labor Relations Act $\$ 9$ (a), 49 Stat. 453 (1935), as amended, 29 U.S.C. $\S 159$ (a) (1952). 
sued the parties to the agreement in an Alabama court. Alleging a federal right to fair representation which had not been respected, he sought to enjoin operation of the discriminatory agreement. The Alabama Supreme Court sustained a demurrer to his complaint, and held that because the Brotherhood had plenary power as exclusive representative under the Railway Labor Act, Steele had no federal right to fair representation. ${ }^{42}$ A unanimous Supreme Court reversed this judgment. Chief Justice Stone's majority opinion rests on the following paragraph:

"Unless the labor union representing a craft owes some duty to represent non-union members of the craft, at least to the extent of not discriminating against them as such in the contracts which it makes as their representative, the minority would be left with no means of protecting their interests, or, indeed, their right to earn a livelihood by pursuing the occupation in which they are employed. While the majority of the craft chooses the bargaining representative, when chosen it represents, as the Act by its terms makes plain, the craft or class, and not the majority. The fair interpretation of the statutory language is that the organization chosen to represent a craft is to represent all its members, the majority as well as the minority, and it is to act for and not against those whom it represents. It is a principle of general application that the exercise of a granted power to act in behalf of others involves the assumption toward them of a duty to exercise the power in their interest and behalf, and that such a grant of power will not be deemed to dispense with all duty toward those for whom it is exercised unless so expressed. ${ }^{43}$

Subsequent cases, all apparently proceeding from the Steele rationale, make it clear that the majority union's duty of fair representation extends to unions regulated by the National Labor Relations Act as well as to those governed by the Railway Labor Act, ${ }^{44}$ to union members as well as nonmembers in the bargaining unit ${ }^{45}$ and to employees in a separate unit who are economically dependent upon the bargain struck in the larger, closely related unit. ${ }^{46}$ The cases also make plain-and this of couse is implicit in Steele-that discrimination not based upon color may violate the union's duty even as discrimination along color lines does. ${ }^{47}$ This statement should not obscure the difference between the cases involving color and those involving other types of discrimina-

42. 245 Ala. 113, 16 So. 2d 416 (1944). The Norris-LaGuardia Act, 47 Stat. 70 (1932), as amended, 29 U.S.C. $\$ \S 101-115$ (1952), notwithstanding, the suit could have been initiated in a federal district court, see Tunstall v. Brotherhood of Locomotive Firemen, 323 U.S. 210 (1944).

43. 323 U.S. at 201-02.

44. Syres v. Local 23, Oil Workers Int'l Union, 350 U.S. 892, reversing per curiam, 223 F.2d 739 (5th Cir. 1955); Wallace Corp. v. NLRB, 323 U.S. 248, 255-56 (1944).

45. Syres v. Local 23, Oil Workers Int'l Union, supra note 44.

46. Brotherhood of Railroad Trainmen v. Howard, 343 U.S. 768 (1952). See Cox, The Duty of Fair Representation, 2 VILL. L. REv. 151, 157-59 (1957); The Supreme Court, 1951 Term, 66 HaRv. L. Rev. 89, 148-49 (1952).

47. See, e.g., Ford Motor Co. v. Huffman, 345 U.S. 330, 337-39 (1953) ; Trailmobile Co. v. Whirls, 331 U.S. 40, 62, 69 (1947) (dissenting opinions of Justices Frankfurter and Jackson). 
tion. Distinctions in a collective agreement which turn upon skin pigmentation are readily branded "unfair." It may well be, however, that particular economic distinctions in a collective agreement are entirely equitable. Indeed, some distinctions are essential..$^{48}$ No one would suggest that wage differentials between skilled and unskilled workers necessarily violate the union's duty of fair representation. In this situation, perhaps, a failure to discriminate would be a breach of duty. On the other hand, a situation can be easily imagined in which an economic distinction has no legitimate basis in industrial experience, and can be explained only as a disregard of the interests of a minority group by the majority union. An obvious case is the union which, subsequent to an organizational campaign, negotiates a collective agreement providing inferior seniority rights for employees who, as the evidence demonstrates, happened openly to oppose unionization..$^{49}$

Even more difficult than separation of unfair from fair in the negotiation of an agreement is making the same distinction in the administration of a collective contract. Quite apart from majority-minority interests which may exist when an agreement is being formed, the union in processing grievances may have an interest in the compromise or settlement of a complaint without regard to its particular merits or the complainant's majority or minority status. "Give a little here to get a little there" is not unknown to this process, and such flexibility may well be to the general benefit. ${ }^{50}$ Yet the employee's interest under a collective agreement sometimes is worthy of more protection than his interest in fair treatment during the negotiations. ${ }^{51}$ It surely is if alleged back pay is involved. Thus, these problems have at least some parallel in familiar legal concepts. Expectations, for example those provided by the existing collective agreement, acted upon with reasonable reliance, would usually be protected. Expectations, alone or with unreasonable reliance-such as the belief that seniority status will not be disturbed by negotiation of a new agreement-often would not be. ${ }^{52}$ The National Labor Relations Act, in a way, recognizes this distinction. It allows an employee, at least in the absence of a contrary provision in a collective bargaining agreement, individually to process his grievance, even

48. See Cox, Labor Law 963 (4th ed. 1958) ; Chamberlain, Collective BargainING 239-57 (1951).

49. Cf. Wallace Corp. v. NLRB, 323 U.S. 248 (1944).

50. See, generally, Cox, Rights Under a Labor Agreement, 69 Harv. L. Rev. 601 (1956) ; see also WiRTz, Due Process of Arbitratron (unpublished paper; copy on file in Yale Law School Library 1958); cf. New YoRk City TrANSIT Aurhoriry FAct Finding Committee, Report to the New York City Transit AuthoRity 15 (Nov. 30, 1957) : "[I]t is now commonly accepted as a sign of maturity and responsibility for labor organizations to screen grievances scrupulously and to rule out those which can serve only to ... satisfy individual desires rather than to give meaning to the labor agreement."

51. See Note, Duty of the Union to Minority Groups in the Bargaining Unit, $65 \mathrm{HaRv}$. L. REv. 490, 495-500 (1952).

52. See Elgin, J. \& E. Ry. v. Burley, 325 U.S. 711 (1945), qualified on rehearing, 327 U.S. 661 (1946). On the general importance in law of this distinction, see Fuller \& Perdue, The Reliance Interest in Contract Damages, 46 Yale L.J. 52 (1936). 
though, under Case, he may not negotiate his conditions of employment..53 This statutory provision may afford some protection to the individual. 54 It also may be harmful to the long range interests of the many represented by the union. ${ }^{\text {to }}$

While the Case doctrine does not apply, at least in its full vigor, to the settlement of grievances, the Steele doctrine does pertain fully to this aspect of collective bargaining. ${ }^{56}$ Since the individual may present his own grievance, the unanswerable logic of Steele is missing; the wisdom of the extension, on the other hand, can hardly be questioned. First, it must be remembered that, quite apart from the majority-rule principle, the union's economic position in the plant has been protected by federal law. ${ }^{57}$ Second, and not unrelated, while the individual may have a right under the statute to present his grievance to his employer, he has very little leverage and probably very little skill. He badly needs fair representation. ${ }^{\text {s8 }}$

In addition to the Steele principle of fair representation, the National Labor Relations Act offers some protection to the minority employee in two ways. Certain job discrimination against nonunion members is an unfair labor prac-

53. " $[A]$ ny individual employee or a group of employees shall have the right at any time to present grievances to their employer and to have such grievances adjusted, without the intervention of the bargaining representative, as long as the adjustment is not inconsistent with the terms of a collective-bargaining contract or agreement then in effect: Provided further, That the bargaining representative has been given opportunity to be present at such adjustment." 61 STAT. 143 (1947), as amended, 29 U.S.C. \$159 (a) (1952). No one has a very clear idea of what this section means. Compare Cox, Rights Under a Labor Agreement, 69 HARv. L. REv. 601, 621-24 (1956), with Report of Committee on Improvement of Administration of Union-Management Agreements, 1954, Individial Grievances, 50 Nw. U.L. Rev. 143 (1955). See Douds v. Local 1250, Retail Wholesale Dep't Store Union, CIO, 173 F.2d 764 (2d Cir. 1949); Hughes Tool Co. v. NLRB, 147 F.2d 69 (5th Cir. 1945), modifying and enfercing 56 N.L.R.B. 981 (1944) ; Dazey Corp., 106 N.L.R.B. 553 (1953). See also Dunau, Employee Participation in the Grievance Aspect of Callective Bargaining, 50 Coluar. L. REv. 731 (1950). Professor Cox is of the view that under the proviso "an employer may lawfully promise the union not to process individual grievances and may also give the union the only legal right to compromise or enforce substantive obligations." Cox, supra at 624. But see Report of Committee on Improvement of Administration of Union-Management Agreements, 1.954, supra at 177-79.

54. See authorities cited note 53 supra.

55. Ibid.

56. Conley v. Gibson, 355 U.S. 41 (1957).

57. See note 22 supra and accompanying text.

58. "The respondents point to the fact that under the Railway Labor Act aggrieved employees can file their own grievances with the Adjustment Board or sue the employer for breach of contract. Granting this, it still furnishes no sanction for the Union's alleged discrimination in refusing to represent petitioners. The Railway Labor Act, in an attempt to aid collective action by employees, conferred great power and protection on the bargaining agent chosen by a majority of them. As individuals or small groups the employees cannot begin to possess the bargaining power of their representative in negotiating with the employer or in presenting their grievances to him. Nor may a minority choose another agent to bargain in their behalf." Conley v. Gibson, 355 U.S. 41, 47 (1957). 
tice ${ }^{59}$ and, under specified conditions, an election to decertify the majority representative is possible. ${ }^{60}$ The latter remedy is desirable but not especially effective in protecting the minority, since to win an election the minority must become a majority. As for the former remedy, it is unfortunate in its present form. Although offering a degree of protection against loss of employment through arbitrary exclusion or expulsion from a union shop, the unfair labor practice, as defined, places undue restrictions upon the union in the administration of its union security provision. In a union shop, all an employee need do to protect his job is "tender the periodic dues and the initiation fees uniformly required as a condition of acquiring or retaining membership ...." If an employee is expelled from a union for a valid reason unrelated to payment of initiation fees or dues-strike-breaking, for instance-the union cannot cause his discharge under its contract. The job and union membership are separated. This provision of the act therefore operates more as a limitation upon union security devices than as a general protection of minority rights. ${ }^{62} \mathrm{By}$ and large, the NLRB is not engaged in safeguarding such rights. ${ }^{63}$ Under the Railway Labor Act also, Steele affords the only general protection. ${ }^{64}$

What, in summary, is the present situation with respect to federal regulation and the individual employee? The national government, by protecting labor unions in their capacity as bargaining representatives from employer and state interference and by requiring good faith negotiation, sponsors collective bargaining as a way of organizing labor-management relations. Collective bargaining as an institution in this country has come to include the Case principle of

59. 61 Stat. 140, 141 (1947), as amended, 29 U.S.C. $\$ \$ 158$ (a) (3), 158 (b) (5) (1952).

60. 61 Stat. 144 (1947), as amended, 29 U.S.C. $\$ 159$ (c) (1) (A) (ii) (1952).

61. 61 Stat. 141 (1947), as amended, 29 U.S.C. $\$ 158$ (a) (3) (1952).

62. The cases are collected and discussed in Daykin, Union Fees and Dues, 9 LAB. L.J. 289 (1958). See also Aaron \& Komaroff, Statutory Regulation of Intemal Union Affairs-I, 44 Ill. L. REv. 425, 446-51 (1949).

63. In proceedings to determine the appropriate bargaining unit, and to certify a union as collective bargaining agent, the NLRB has sometimes paid lip service to the principles of Steele. See Larus \& Bros. Co., 62 N.L.R.B. 1075, 1081 (1945). But it has done no more than this. Compare Bethlehem-Alameda Shipyard, Inc., 53 N.L.R.B. 999 (1943), with Veneer Products, Inc., 81 N.L.R.B. 492 (1949). See Aaron \& Komaroff, supra note 62, at 438-46; Note, 65 HARv. L. REv. 490, 492-93 (1952).

It has been suggested that the Board has jurisdiction to apply the Steele doctrine in complaint cases. National Labor Relations Act $\$ 8$ (b) (3), 61 STAT. 140 (1947), as amended, 29 U.S.C. § 158 (b) (3) (1952), imposes a duty on the union to bargain in good faith. But is failure to represent all employees fairly a violation of this section? The question has not been passed upon directly by Board or courts. See Ford Motor Co. v. Huffman, 345 U.S. 330, 332 n.4 (1953). An affirmative answer is persuasively articulated in Cox, The Duty of Fair Representation, 2 VILL. L. Rev. 151, 172-75 (1957). See also Note, 65 HARv. L. Rev. 490, 494 n.46 (1952).

64. The union shop provision of the Railway Labor Act, 64 STAT. 1238 (1951), 45 U.S.C. $\$ 152$ (Eleventh) (1952), is similar to the union security provisions of the National Labor Relations Act cited note 59 stupra. The administrative bodies established by the Railway Labor Act afford no protection to the minority railroad employee. See Aaron \& Komaroff, supra note 62 , at $428-38$. 
majority rule. Consequently, federal sponsorship of collective bargaining imposes an obligation on the federal government to protect the minority employee from abuse by the majority union. But the agencies established under the Railway Labor Act and the National Labor Relations Act do not effectively secure minority rights. And although the federal government under Steele has attempted to discharge its obligation by imposing a duty of fair representation upon the majority union, and by granting to employees a remedy in the courts for breach of this duty, complexities of industrial life make it difficult to tell a fair distinction in the negotiation or administration of a collective agreement from an unfair one. Given this background, is it not doubtful whether present federal law, which is mainly the Steele doctrine, satisfactorily discharges the government's obligation to the individual employee? Instinct suggests that the answer is yes; evidence substantiates the surmise.

\section{Steele Doctrine Difficulties}

Not only is it an expensive and upsetting experience for an employee to go to court but, once there, he finds it extremely difficult to prove that nonracial distinctions made in the negotiation or administration of a collective agreement constitute illegal discrimination. Courts simply do not have the standards by which to adjudge such distinctions fair or unfair. ${ }^{65}$ The Steele case did produce one standard which has found great favor. "We think that the ... Act imposes upon the statutory representative of a craft at least as exacting a duty to protect equally the interests of the members of the craft as the Constitution imposes upon a legislature to give equal protection to the interests of those for whom it legislates." Analogy to the equal protection clause works well enough where distinctions are drawn upon the basis of race, color or creed. But it is difficult to judge irrational, unreasonable or arbitrary economic distinctions which arise in collective bargaining. Suppose that company $B$ is acquired by company $A$, that the $B$ employees go to work at $A$ where they are outnumbered ten to one, and that the union in $A$, which is clearly the representative of a majority of employees, is certified by the NLRB as exclusive representative. If it and the company negotiate a collective agreement treating all of the former $B$ people as new employees for seniority purposes, has the union violated its obligation of fair representation to the old workers of $B$ ? This is more than a law professor's examination question. With slight variations, the situation appears again and again in our industrial jurisprudence. ${ }^{67}$ Here, the classification established

65. On the question of standards where discrimination is nonracial, see Cox, The Duty of Fair Representation, 2 VILL. L. REv. 151, 166-69 (1957); Notes, 62 YALE L.J. 282 (1953), 65 Harv. L. Rev. 490 (1952). See also section entitled FaIr Representatton infra.

66. 323 U.S. at 202.

67. See Kahn, Seniority Problems in Business Mergers, 8 IND. \& LAB. REL. REv. 361 (1955). Probably the most notorious and certainly the most instructive situation is told in the series of cases known as the Trailmobile litigation. See Trailer Co., 51 N.L.R.B. 1106 (1943); Trailer Co., 53 N.L.R.B. 1248 (1943); Hess v. Trailer Co., 31 Ohio Op. 
by the labor contract can hardly be held arbitrary. Since the seniority of some employees had to be reduced, the union simply chose an arrangement which was the least damaging to the seniority status of the greatest number of employees in the unit. The equal protection clause certainly demands no more of the states. ${ }^{68}$ The wisdom of an analogy to the equal protection clause when determining the legality of economic distinctions in collective bargaining agreements is, however, extremely questionable.

The metaphor which likens a labor agreement to a piece of legislation can be as misleading as an attempt to equate such a document to a commercial contract. It is useful when employed to disabuse the uninitiated lawyer of naive beliefs, but should not be taken seriously as describing the union's duty of fair representation in the collective bargaining process. The analogy preposterously mistepresents the status of labor unions in our society by suggesting that their collective bargaining decisions should be accorded the same respect under federal law as the decisions of state legislatures. The states are not institutions which have been delegated power by the federal government. Indeed, is it not the other way around? The labor union, by contrast, is the beneficiary of just such delegated federal power. ${ }^{69}$ A responsible government must be intensely concerned with the way in which a private organization exercises this type of power. The equal protection clause is inappropriate for this purpose because it regulates an altogether different kind of relationship.

Since unions are the beneficiaries of delegated federal power, could not workable standards be found by analogies to the field of administrative law? This

566 (C.P. 1944) ; Whirls v. Trailmobile Co., 64 F. Supp. 713 (S.D. Ohio 1945), aff'd, 154 F.2d 866 (6th Cir. 1946), rev'd, 331 U.S. 40 (1947) ; Britt v. Trailmobile Co., 179 F.2d 569 (6th Cir.), cert. denied, 340 U.S. 820 (1950). See also Notes, 65 Harv. L. Rev. 490, 498-500 (1952), 36 Ohio Op. 390 (1948).

68. Morey v. Doud, 354 U.S. 457, 463-64 (1957) :

"[W]e start with the established proposition that the "prohibition of the Equal Protection Clause goes no further than the invidious discrimination. . . . The rules for testing a discrimination have been summarized as follows:

'1. The equal protection clause of the Fourteenth Amendment does not take from the State the power to classify in the adoption of police laws, but admits of the exercise of a wide scope of discretion in that regard, and avoids what is done only when it is without any reasonable basis and therefore is purely arbitrary. 2 . A classification having some reasonable basis does not offend against that clause merely because it is not made with mathematical nicety or because in practice it results in some inequality. 3. When the classification in such a law is called in question, if any state of facts reasonably can be conceived that would sustain it, the existence of that state of facts at the time the law was enacted must be assumed. 4. One who assails the classification in such a law must carry the burden of showing that it does not rest upon any reasonable basis, but is essentially arbitrary....'

To these rules we add the caution that 'Discriminations of an unusual character especially suggest careful consideration to determine whether they are obnoxious to the constitutional provision."

69. See text at note 22 supra. 
undertaking would probably prove fruitless. A federal administrative agency is composed of individuals nominated for office by the President and confirmed by the Senate. ${ }^{70}$ It makes economic decisions in accordance with relatively strict procedural safeguards ${ }^{71}$ and is, in conception at least, wholly disinterested. The method of selecting labor union officers, the procedures which govern the decision-making process within the union and the relation of the union as an organization to the economic decisions it resolves, reveal an institution having as little similarity to a federal administrative agency as it has to a state legislature. ${ }^{72}$

What standards courts have in fact employed to test the fairness of economic distinctions in the negotiation and administration of the labor agreement is unclear. The inappropriate words of constitutional law are found in the opinions. ${ }^{73}$ And some decisions indicate no awareness whatever of the problem. ${ }^{74}$ The Supreme Court, in 1953, provided additional guidance by declaring that "a wide range of reasonableness must be allowed a statutory bargaining representative in serving the unit it represents, subject always to complete good faith and honesty of purpose in the exercise of its discretion."'75

What is clear is that courts have not found it easy to devise standards which are institutionally sound in this esoteric world of collective bargaining. More often than not, this difficulty has been recognized and has tended to restrain judicial intervention. A heavy presumption of regularity, not unlike the presumption of constitutionality which quite properly attaches to judicial review of state economic action, is employed in court hearings on union action. ${ }^{76}$ This

70. See, e.g., 61 Stat. 139 (1947), 29 U.S.C. $\$ 153($ a) (1952).

71. See, e.g., 61 Stat. 143, 144 (1947), as amended, 29 U.S.C. $\$ \$ 159,160$ (1952).

72. See Bakke \& Kerr, Unions, Management and tHe Purlic 180 (1948) ; Goldstein, The Government of a Brittsh Trade Union (1952) ; Lipset, Trow \& ColeMAN, UNION DEMTOCRACY (1956).

73. See, e.g., Colbert v. Brotherhood of Railroad Trainmen, 206 F.2d 9, 13 (9th Cir. 1953), cert. denied, 346 U.S. 931 (1954) ; Britt v. Trailmobile Co., 179 F.2d 569, 573 (6th Cir.), cert. denicd, 340 U.S. 820 (1950); Napier v. System Federation No. 91, Railway Employes' Dep't, AFL, 127 F. Supp. 874, 886 (W.D. Ky. 1955) ; Hargrove v. Brotherhood of Locomotive Engineers, 116 F. Supp. 3, 8 (D.D.C. 1953).

Sometimes, federal labor policy embodied in federal statutes will supply the appropriate standard. See Wallace Corp. v. NLRB, 323 U.S. 248 (1944); Note, 65 Harv. L. Rev. 490, 493 (1952). Or other federal policy may serve as a guide. See Ford Motor Co. v. Huffman, 345 U.S. 330 (1953) (Selective Service Act of Sept. 16, 1940, c. 720, $\S 8,54$ StAT. 890 ).

74. See, e.g., Lewellyn v. Fleming, 154 F.2d 211 (10th Cir. 1946) ; Jennings v. Jennings, 91. N.E.2d 899 (Ohio Ct. App. 1949). Indeed, some courts have erroneously suggested that the Steele principle applies only to racial discrimination. See, e.g., Spires v. Southern Ry., 204 F.2d 453, 456-57 (4th Cir. 1953).

75. Ford Motor Co. v. Huffman, 345 U.S. 330, 338 (1953). See Mount v. Grand Int'1 Brothèrhood of Locomotive Engineers, 226 F.2d 604 (6th Cir. 1955), cert. denied, 350 U.S. 967 (1956) ("hostile discrimination" as test).

76. See cases cited note 73 supra. See also Cortez v. Ford Motor Co., 349 Mich. 108, 121, 84 N.W.2d 523, 529 (1957); Walker v. Pennsylvania-Reading Seashore Lines, 142 N.J. Eq. 588, 604, 61 A.2d 453, 463-64 (Ch. 1948) ; Brotherhood of Railroad Trainmen v. Luckie, 286 S.W.2d 712, 715-16 (Tex. Civ. App. 1955). 
imposes a strenuous burden of proof upon a plaintiff. ${ }^{77}$ Recourse to the presumption represents an approach which on its face does not discharge the federal government of its responsibility to the individual, a responsibility which stems from federal protection of labor unions, and from the majority-rule concept of collective bargaining.

In seeking a method for discharging this responsibility, commentators have suggested-and it is a powerful suggestion-that if the individual employee belongs to the union, has freedom within the organization to communicate his economic needs to his officers and holds political power to influence their action, or indeed, to become an officer himself, the potential for unfair distinctions in collective bargaining will be reduced. ${ }^{78}$ Unfortunately, so happy a state does not exist in all unions ${ }^{79}$ and probably cannot be created by law alone. ${ }^{80}$ Even if it could, economic abuse of a minority group by a majority through a democratic process would not be precluded. ${ }^{81}$ But the image of an employee with such rights suggests a partial solution to the problem of federal responsibility. Specifically, legislation could require the majority union to admit to membership each employee in the bargaining unit; protect the member in his political activity within the labor organization by limiting the union's power to discipline him for such activity; and guarantee the member free and relatively frequent union elections. ${ }^{82}$ Is it not appropriate, then, for the federal government, in the discharge of its obligation to the individual employee, to legislate along these lines,

77. See Ford Motor Co. v. Huffman, 345 U.S. 330 (1953) ; Britt v. Trailmobile Co., 179 F.2d 569 (6th Cir.), cert. denied, 340 U.S. 820 (1950) ; Lewellyn v. Fleming, 154 F.2d 211 (10th Cir. 1946); Gaskill v. Roth, 151. F.2d 366 (8th Cir. 1945) ; Napier v. System Federation No. 91, Railway Employes' Dep't, AFL, 127 F. Supp. 874 (W.D. Ky. 1955); cf. Kordewick v. Brotherhood of Railroad Trainmen, 181 F.2d 963 (7th Cir. 1950); Hughes v. Chicago, R.I. \& Pac. R.R., 26 L.R.R.M. 2317 (W.D. Okla. 1950) ; Cortez v. Ford Motor Co., supra note 76. See also Pellicer v. Brotherhood of Ry. \& S.S. Clerks, 118 F. Supp. 254, 258 (S.D. Fla. 1953) ("It is significant that in cases where challenged change's in seniority provisions did not involve racial discrimination, the courts consistently have refused to upset the agreement") ; Kahn, supra note 67, at 378 ("Except in certain regulated industries, the parties to collective bargaining have considerable latitude in this situation. They may reject integration, thus submerging one group to the other for seniority purposes, or adopt any particular integration formula which is agreed upon. The courts have recently reaffirmed a judicial reluctance to intrude upon this aspect of the content of collective bargaining"). Compare Brown, Employee Protection and the Regulation of Public Utilities: Mergers, Consolidations, and Abandonment of Facilities in the Transtortation Industry, 63 YALE L.J. 445 (1954).

78. See S. Rep. No. 1684, 85th Cong., 2d Sess. 4 (1958) ; Cox, The Role of Law in Preserving Unton Democracy (unpublished paper; copy on file in Yale Law School Library 1958) ; Rauh, Civil Rights and Liberties and Labor Unions, 8 LAB. L.J. 874, 875 (1957).

79. See authorities cited note 8 supra.

80. See Summers, The Usefulness of Law in Achieving Union Democracy, 48 Axs. Econ. Rev. 44 (Supp. 1958).

81. See section entitled Minority Interests and Majority Power infra.

82. See Kerr, Unions and Union Leaders of Their Own Choosing, in Selected ReadINGs 105; Summers, Legislating Union Democracy, in id. at 250. 
not in substitution for the Steele doctrine, but rather in aid of Steele's requirement of fair representation? An affirmative answer would be easy were analysis to terminate at this point. But, so far, the case for legislation rests only on a showing that the federal government has a basis in present federal law for an interest in assuring democratic union government. Account must be taken of another element of the problem. In many states, law already exists dealing with internal union affairs. Perhaps this body of law goes as far as law can go to assure democratic union government. If so, additional federal legislation would be redundant.

\section{State Protection of the Employee's Interest in Admission, Discipline AND ELECTIONS}

\section{Admission}

California appears to be the only state which, in the absence of legislation, has ordered a union to admit an individual to membership. ${ }^{83}$ Its supreme court accomplished this result without fanfare in the recent case of Thorman v. International Alliance of Theatrical Stage Employees. ${ }^{84}$ The litigation grew out of a situation involving a closed union and a closed shop. Prior to Thorman, under California's fairly mature body of common law dealing with this recurring problem, ${ }^{85}$ an individual denied work because unfairly barred from a union or denied full membership rights because of race, color or creed, could obtain no more than an order compelling the union either to admit him to membership or to refrain from enforcing its closed shop agreement against him. This is job protection. Several states-apparently all jurisdictions in which the issue has been litigated-protect an employee in this fashion under some circumstances. $^{80}$ The Thorman court's order was not alternative in form but simply commanded the admission of plaintiff to membership in defendant union. ${ }^{87}$ Unfortunately, however, the majority and dissenting judges addressed their opinions exclusively to the question of federal pre-emption-to whether the sections of the National Labor Relations Act separating the job from the

83. On the general subject of admissions, see Summers, The Right To Join a Union, 47 Colum. L. Rev. 33 (1947) ; Summers, Admission Policies of Labor Unions, 61. Q.J. Econ. 66 (1946). Cf. Betts v. Easley, $161 \mathrm{Kan} .459,169$ P.2d 831 (1946).

84. 49 Cal. 2d 638, 320 P.2d 494 (1958), modifying and affirming 149 Cal. Adv. App. 116, 307 P.2d 1026 (App. Dep't 1957).

85. See Williams v. International Brotherhood of Boilermakers, $27 \mathrm{Cal}$. 2d 586, 165 P.2d 903 (1946) ; James v. Marinship Corp., 25 Cal. 2d 721, 155 P.2d 329 (1944) ; Riviello v. Journeymen Barbers Union, 88 Cal. App. 2d 499, 199 P.2d 400 (1948).

86. See Summers, The Right To Join a Union, 47 Colum. L. Rev. 33, 44-51 (1947) (collecting cases). See also Clark v. Curtis, 297 N.Y. 1014, 80 N.E.2d 536 (1948). With respect to the situation under the National Labor Relations Act and the Railway Labor Act, see notes 59-64 supra and accompanying text. See also Ryan v. Simons, 25 L.R.R.M. 2302 (N.Y. Sup. Ct.), temporary injunction finalized, 98 N.Y.S.2d 243 (Sup. Ct.), rev'd, 277 App. Div. 1000, 100 N.Y.S.2d 18 (2d Dep't 1950), aff'd, 302 N.Y. 742, 98 N.E.2d 707, modified, 302 N.Y. 847, 100 N.E.2d 44, cert. denied, 342 U.S. 897 (1951).

87. 49 Cal. 2d 638, 320 P.2d 494 (1958). 
union and protecting the job eliminate state court jurisdiction. ${ }^{88}$ The importance of the Thorman departure is therefore unclear, since it is impossible to say why Thorman was.

Except for this single case, one may safely conclude that at common law the states do not protect the employee's interest in admission to a labor union. The explanation generally advanced for this unhappy situation is an anachronism: because unions are private clubs, membership is a privilege and not a right. ${ }^{80}$

On the other hand, something of a right to membership is given in some jurisdictions by statute. ${ }^{90}$ Several states have fair employment practice acts reaching the most offensive type of abuse-discrimination based on race, color or creed. ${ }^{91}$ The New York statute is a model:

"It shall be an unlawful discriminatory practice ... . for a labor organization, because of the age, race, creed, color or national origin of any individual, to exclude or to expel from its membership such individual or to discriminate in any way against any of its members or against any employer or any individual employed by an employer."92

There is some statutory regulation of initiation fees, ${ }^{93}$ and Colorado, in addition to a Fair Employment Practice Act, has a statute which declares:

88. International Ass'n of Machinists v. Gonzales, 356 U.S. 617 (1958), although not precisely in point, indicates that the majority in Thorman is quite correct on the preemption issue.

89. See Frank v. National Alliance of Bill Posters, 89 N.J.L. 380, 381, 99 Atl. 134, 135 (1916) ("It would be quite impracticable for the courts to undertake to compel men to receive into their social relationships one who was personally disagreeable whether for a good or a bad reason. Property rights [of unincorporated unions] the courts can deal with .... while they cannot, by a mandatory writ, intrude one man's companionship on another"); of. Harris v. Thomas, 217 S.W. 1068, 1076-77 (Tex. Civ. App. 1920) ("A voluntary association has the power to enact laws governing the admission of members and to prescribe the necessary qualifications for membership. . . . Membership therein is a privilege which the society may accord or withhold at its pleasure, with which a court of equity will not interfere, even though the arbitrary rejection of the candidate may prejudice his material interest").

90. See Aaron \& Komaroff, supra note 62 , at $452-59$.

91. Alaska Sess. Laws 1953, c. 18; Colo. Rev. Stat. Anv. \$\$ 80-24-1 to -\$ (Supp. 1957) ; Conn. Gen. Stat. $\$ \$ 7400-07$ (Supp. 1955) ; Ind. Ann. Stat. $\$ \S 40-2301$ to -2306 (Supp. 1955) ; Kan. Gen. Stat. Ann. \$§ 44-1001 to -1008 (Supp. 1957) ; Mass. Ann. Laws c. 151B, §§ 1-10 (Supp. 1957) ; Mrch. Stat. ANo. \$§ 17.458(1)-(11) (Supp. 1957); Minnn. Stat. Ann. \$\$ 363.01-.07 (Supp. 1957) ; N.J. STAT. ANn. \$\$ 18.25-1 to -2\$ (Supp. 1957) ; N.M. Stat. ANN. \$\$ 59-4-1 to -14 (Supp. 1957) ; N.Y. Executtve Law \$\$ 290-301; Ore. Rev. Stat. Ann. $\$ \S 659.010-110,659.990$ (1957) ; PA. Stat. Ann. tit. 43, $\$$ 951-63 (Supp. 1957) ; R.I. Gen. Laws ANN. \$§ 28-5-1 to -39 (Supp. 1957) ; Wash. Rev. Code Ann. $\S \S 49.60 .010-.320$ (1957) ; Wis. STAT. ANN. $\S \S 111.31-.36$ (1955). The Indiana, Kansas and Wisconsin statutes have no enforcement procedures while the Colorado statutes provide enforcement procedures only against public employers. See Tre Group of Teachers and Practitioners of Labor Law, The Employment Relation and the LAW 58 (1957); Note, 68 Harv. L. Rev. 685 (1955).

92. N.Y. Executrve Law $\S 296(1)$ (b). See also N.Y. Civ. Rights Law $\$ 43$, held not to violate due process or equal protection in Railway Mail Ass'n v. Corsi, 326 U.S. $8 S$ (1945).

93. See, e.g., Fla. Stat. AnN. $\$ 447.05$ (Supp. 1957) ("Labor unions . . shall not 
"All rights of persons to join labor organizations or unions and their rights and privileges as members thereof, should be recognized, safeguarded and protected. No person shall be denied membership in a labor organizazation or union on account of race, color, religion, sex or by any unfair or unjust discrimination."94

But most states have no legislation; accordingly, the employee's interest in membership remains largely unprotected.

\section{Discipline}

A considerable and evolving body of state law protects a member from unfair expulsion or suspension from his union. ${ }^{95}$ Almost wholly judge-made, this law extends to the substance as well as the procedure of union disciplinary action. ${ }^{96}$ Unfortunately, the legal protection afforded by the judiciary seems less than satisfactory: substantively, because of the institutional limitations of the courts; procedurally, because the union's disciplinary bodies are often not disinterested. The latter difficulty is apparent once it is realized that disciplinary proceedings may be instituted against a member for conduct alleged to be contrary to union policy, ${ }^{97}$ and brought before a tribunal controlled by the policy-making, and hence the interested, group in the union. ${ }^{98}$ Upon judicial review of a union proceeding, covert bias can easily go undetected. ${ }^{99}$

charge an initiation fee in excess of the sum of fifteen dollars); cf. ALA. Code ANv. tit. $26, \S 390$ (Supp. 1955) (forbidding fee for work permit). The constitutionality of the Alabama statute was upheld in Alabama State Federation of Labor v. McAdory, 246 Ala. 1 , 18 So. 2d 810 (1944), cert. dismissed, 325 U.S. 450 (1945).

94. Colo. Rev. Stat. Ann. $\$ 80-5-1$ (4) (Supp. 1957).

95. On the general problem of discipline, see Summers, Disciplinary Powers of Unions, 3 Ind. \& LAB. REL. Rev. 483 (1950) ; Summers, Disciplinary Procedures of Unions, 4 IND. \& LAB. Rec. Rev. 15 (1950) ; Summers, Legal Limitations on Union Discipline, 64 Harv. L. REv. 1049 (1951) (a three part study of the disciplinary procedures prescribed in 154 international union constitutions and of union practices under them, together with 218 related court, board and arbitration decisions). See also the pioneering article of Professor Chafee, The Internal Affairs of Associations Not for Profit, 43 HARv. L. Rev. 993 (1930).

96. State statutory law-the little there is-is examined in Aaron \& Komaroff, Statutory Regulation of Internal Union Affairs-I, 44 ILL. L. REv. 425, $451-65$ (1949).

97. "[T] he number of prohibitions stated is usually relatively small, but they are frequently expressed in broad and vague terms such as the provision in the United Electric Workers Constitution punishing 'offenses against ... the general good and welfare of the Union.' "Summers, Disciplinary Powers of Unions, 3 IND. \& LAB. REL. REv. 483, 493-94 (1950). See also id. at 496-98.

98. "Members who seek to challenge those in power by engaging in internal political action may be accused of violating either general or specific constitutional provisions. They are found guilty by a procedure which may be completely controlled by those whose positions are threatened, and their appeal may be to officers who are political allies of the prosecutors." Summers, Disciplinary Procedures of Unions, 4 Ind. \& LAB. REI. REv. 15, 29-30 (1950).

"The typical discipline procedure includes the following major steps: making of charges by a fellow member, serving of notice on the accused, naming of a trial committee, holding of a hearing, reporting of recommendations to the local union for vote, and appealing to international officers and the international convention." Id. at 15.

99. See, e.g., Dragwa v. Federal Labor Union, 136 N.J. Eq. 172, 41 A.2d 32 (Ch. 
Judicial review of a substantive question requires the court to judge the issue by some standard. The problem is where this standard is to be found. Rare indeed is a judge whose personal conclusions will be institutionally sound. And the court, because of its own functional limitations, cannot readily acquaint itself with the institution it must judge. Quite naturally-and properly-therefore, the standards contained in the union constitution and by-laws are the principal guides to which a court will turn. ${ }^{100}$

These documents are said to be a contract between the member and his union. ${ }^{101}$ Of course, they are not a negotiated contract; they are not a contract at all.102 This lack of precision, however, is of small moment. The least sophisticated judge in a union disciplinary proceeding knows that the action is $e x$ contractu only in a Pickwickian sense. The difficulty with the approach, as well as its strength, lies in the source of the standards. Union people know best about unions. But they may be overprotective about their organization and include within its constitution provisions which restrict rank-and-file opposition. ${ }^{103}$ Furthermore, the union member has extra-union rights and obligations which the union constitution may ignore. Conduct which is not in the best interest of the union, for example, may under the union constitution be subject to discipline. Support of an allegedly anti-union congressman by a member would by this standard seem to be an offense. Rights of citizenship must be paramount, however, and most courts would hold void as against public policy a clause making such support punishable. ${ }^{104}$ Thus, it is apparent that a court

1945 ) ; State ex rel. Dame v. LeFevre, 251 Wis. 146, 28 N.W.2d 349 (1947) (semble); Note, 57 Y ALE L.J. 1302 (1948). See also Chamberlain, The Judicial Process in Labor Unions, 10 Brooklyn L. Rev. 145, 162-65 (1940) ; Summers, Legal Limitations an Union Discipline, 64 Harv. L. Rev. 1049, 1082-84 (1951).

100. See, e.g., Sanders v. International Ass'n of Bridge Workers, 235 F.2d 271 (6th Cir. 1956) ; Otto v. Journeymen Tailors' Union, 75 Cal. 308, 17 Pac. 217 (1888).

101. "The constitution and by-laws of an unincorporated association express the terms of a contract which define the privileges secured and the duties assumed by those who have become members." Polin v. Kaplan, 257 N.Y. 277, 281, 177 N.E. 833, 834 (1931).

102. See Summers, Legal Limitations on Union Discipline, 64 HARv. L. REv. 1049, 1054-58 (1951).

103. See Summers, Disciplinary Powers of Unions, 3 IND. \& LAB. REL. Rev. 483, 498-501 (1950). The judicial attitude towards constitutional provisions which limit political activity within the union is not uniform. Compare Reilly v. Hogan, 32 N.Y.S.2d 864 (Sup. Ct.), aff'd, 264 App. Div. 855, 36 N.Y.S.2d 423 (1st Dep't 1942), with Elfer v. Marine Engineers Ass'n, 179 La. 383, 154 So. 32 (1934). When the member is protectedand he often is-the judgment is likely to be grounded upon irregularities in procedures followed by the union, see, e.g., Harris v. National Union of Marine Cooks, 98 Cal. App. 2d 733, 221 P.2d 136 (1950), rather than upon a determination that the union's substantive standard is improper.

104. In Spayd v. Ringling Rock Lodge, $270 \mathrm{~Pa}$. 67, 113 Atl. 70 (1921), the court held that a provision in a union constitution which prohibited members from interfering with legislative activities of the union was "against public policy and void" when invoked by the union to expel a member who signed a petition advocating legislative action contrary to the union's position. See also Abdon v. Wallace, 95 Ind. App. 604, 165 N.E. 68 (1929). But cf. Harrison v. Brotherhood of Ry. \& S.S. Clerks, 271 S.W.2d 852 (Ky. Ct. App. 
will reach beyond the standards supplied by the union. Understandably, courts are reluctant to do so.

Union democracy is likely to suffer from these limitations of court review, aggravated at times by delay in obtaining judicial relief or by strict application of the doctrine requiring exhaustion of internal union remedies. ${ }^{105}$ Too oftenalthough not frequently because most unions must in this respect be accounted democratic-the member who speaks his mind about intraunion affairs, who stands up to the leadership, finds himself either unprotected by the courts, or protected, but too late to save a delicate growth of opposition within his union.

\section{Elections}

Because union constitutions are generally explicit and right-minded in their treatment of election procedures, the contract theory safeguards the union member's interest in fair elections more successfully than it does in disciplinary proceedings. ${ }^{100}$ Judicial protection extends to the individual who seeks nomination or election to an office and claims an irregularity. ${ }^{107}$ It is extended with perhaps more enthusiasm to the rank-and-file member who sues in a representative capacity claiming improprieties which denied him and his fellow members an opportunity to vote in a fair election. ${ }^{108}$ In these cases, the plaintiff-member

1954). In Morgan v. Local 1150, United Elec. Workers, 16 L.R.R.M. 720 (I11. Super. Ct. 1945), rev'd on other grounds, 331 I1l. App. 21, 72 N.E.2d 59 (1946), the court protected the individual who supported a candidate for public office opposed by the union. But cf. DeMille v. American Federation of Radio Artists, 31 Cal. 2d 139, 187 P.2d 769 (1947), cort. denied, 333 U.S. 876 (1948); Pfoh v. Whitney, 62 N.E.2d 744 (Ohio Ct. App. 1945). One right of citizenship generally recognized by the courts as paramount is the member's right-if an actual controversy exists-to sue the union irrespective of a constitutional provision prohibiting such action. See Collins v. International Alliance of Theatrical Employes, 119 N.J. Eq. 230, 248, 182 Atl. 37, 46 (Ch. 1935). For cases of a somewhat different order, where rights of citizenship were deemed paramount, see Schneider v. Local 60, United Ass'r Journeymen Plumbers, 116 La. 270, 40 So. 700 (1905); Manning v. Klein, 1 Pa. Super. 210 (1896).

105. "It is a well-settled rule that one who is expelled from a fraternal society cannot resort to the courts until he has exhausted his remedies within the society. This rule has been transferred to apply to labor unions and at times has been vigorously enforced. However, its binding effect has been severely weakened by the large number of exceptions which the courts have created to excuse exhaustion of internal remedies." THE Group of Teachers and Practitioners of Labor Law, Labor Relations and the Law 913 (1953). See also Vorenberg, Exhanstion of Intrantnion Remedies as a Condition Precedent To Appcal to the Courts, 2 LAB. L.J. 487 (1951).

106. See Dankert, Contemporary Unronism in the United States $206-16$ (1948); Shister, Trade-Union Government: A Formal Analysis, 60 Q.J. Ecos. 78, 90 (1945); Summers, Union Powers and Workers' Rights, 49 MicH. L. Rev. 805, 830 (1951).

107. See, e.g., Lacey v. O'Rourke, 147 F. Supp. 922 (S.D.N.Y. 1956). The plaintiff, before he can obtain relief, must exhaust his intraunion remedies. See Harrison v. O'Neill, 26 L.R.R.M. 2294 (N.Y. Sup. Ct. 1950).

108. See, e.g., Collins v. International Alliance of Theatrical Employees, 119 N.J. Eq. 230, 182 Atl. 37 (Ch. 1935) ; Fisher v. Kempter, 25 L.R.R.M. 2188, 2189 (N.Y. Sup. Ct. 1949). 
is claiming an intangible sort of right; the claim in the past has given courts, viewing labor unions as private social clubs, some trouble. ${ }^{109}$ The analogy to the club generally tends to restrain judicial intervention, for courts have often said that a "property right" must exist to justify their intrusion. ${ }^{110}$ While "property right" is, of course, an extraordinarily vague concept, expulsion from a union is nearer the archetype evoked by the phrase than an unfair election proceeding. ${ }^{111}$ But it seems probable today that most courts will follow the New York judge who manifested his wisdom in the course of an opinion when he said: "[A] labor union is not a social club. ... The success of the result is dependent upon the responsiveness and ability of the leader of the union. ... If a member has a 'property right' in his position on the roster, I think he has an equally enforcible property right in the election of men who will represent him ...."112

This adumbration of state law has been adequate, I should think, to justify venturing one inescapable as well as another possibly debatable conclusion. First, the states are deeply involved in the regulation of internal union affairs. Second, state action in the form of legislation and judge-made law has not, in the majority of jurisdictions, served to discharge the federal government's obligation to the individual employee.

Recapitulation may help justify this latter conclusion. State law has been surveyed to determine whether it helps secure the worker fair representation in the negotiation and administration of the collective agreement by protecting his freedom within the union to make felt his economic needs. The thought has been that if the individual can communicate these needs through a democratic political process within the union, the Steele doctrine will be reinforced and the federal government's duty to the individual, imposed by the majorityrule concept of collective bargaining, will more nearly be satisfied. The survey has been concerned with admission, discipline and election in the belief that employee protection in these three areas is both susceptible to legislation and of maximum importance-even though such protection may not, by itself, be enough for success. But state protection of the employee's interest in admission is, as indicated, inadequate. Indeed, it is by and large nonexistent. While the situation is more encouraging in the area of discipline and even more so as to elections, standards come mostly from the unions themselves and hence may be unsatisfactory. Furthermore, union tribunals may be biased, and the law's delay intolerable.

109. Compare Carey v. International Brotherhood of Paper Makers, 123 Misc. 680, 206 N.Y. Supp. 73 (Sup. Ct. 1924), with Talton v. Behncke, 199 F.2d 471 (7th Cir. 1952).

110. See cases cited notes 109 supra, 112 infra.

111. "The right to participate in the establishment and management of the government of the union through voting for its officers and the privilege of becoming a candidate for an office therein is a political right incident to the privilege of membership. It involves no property right ...." State ex rel. Givens v. Superior Court, 233 Ind. 235, 240, 117 N.E.2d 553, 556 (1954).

112. Dusing v. Nuzzo, 177 Misc. 35, 37, 29 N.Y.S.2d 882, 884 (Sup. Ct. 1941). 
Before action upon these conclusions is warranted, however, a further area of inquiry must be pursued. The labor movement itself may be responding and, through publicly coerced private action, may reduce the pressure on the federal government to legislate about union democracy.

\section{Priviate Regulation of Union Democracy}

Two events have occurred recently within the union movement which should encourage the proponent of union democracy. First, two important unions, the Auto Workers and the Upholsterers, have established review boards staffed by wholly independent citizens of stature in the community, and generally of expertness in the labor field. ${ }^{113}$ These boards have broad jurisdiction, including the power to review internal disciplinary proceedings. ${ }^{114}$ There is every reason to expect that both of these private boards will offer the union member protection comparable to any that might be provided by legislation. There is reason to hope, though not to expect, that other unions less democratic in character will follow the lead of these pioneering organizations.

Second, the AFL-CIO Executive Council approved on May 23, 1957, an Ethical Practices Code for the combined labor organization, titled Union Democratic Processes, dealing with some of the problems with which this Article is concerned. ${ }^{115}$ The first provision of the Code is of special interest.

"Each member of a union should have the right to full and free participation in union self-government. This should include the right (a) to vote periodically for his local and national officers, either directly by referendum vote or through delegate bodies, (b) to honest elections, (c) to

113. The Upholsterers Review Board was established in May 1954. Appointees to the Board at that time were Archibald Cox of the Harvard Law School, chairman; Nathan P. Feinsinger, University of Wisconsin Law School; Paul M. Herzog, then Assistant Dean of the Harvard School of Public Administration; Father Leo $C$. Brown of St. Louis University; J. Benton Gillingham, Assistant Director of the University of Washington Institute of Labor Economics; Father Dennis J. Comey of the Institute of Industrial Relations at St. Joseph's College; Clark Kerr, Chancellor of the University of California; Curtis J. Bok, Judge of the Court of Common Pleas, Philadelphia; and Joseph D. Lohman, Former Chairman of the Illinois State Parole Commission. See 34 L.R.R.M. 65 (1954).

The United Auto Workers Appeal Board was created on April 12, 1957, at that union's sixteenth convention. Six persons were then appointed to the board: Rabbi Morris Adler of Detroit; Monsignor George C. Higgins of Washington, D.C.; Clark Kerr; Edwin E. Witte, University of Wisconsin; Wade H. McCree, Judge of the Detroit Circuit Court; and Bishop G. Bromley Oxnam of Washington, D.C. See 39 L.R.R.M. 42 (1957). For a recent discussion of its activities, see Bus. Week, July 12, 1958, pp. 81-88.

114. See 34 L.R.R.M. 65 (1954); 39 L.R.R.M. $41-42$ (1957). The UA.W Board has jurisdiction to review both the fairness of the union's treatment of an individual's grievance and the union's disciplinary action. The only case decided thus far by the Upholsterers' Board was apparently of the former type. In addition to its status as an appellate tribunal, the UAW Board has a "watchdog" function. Ibid.

115. See Code VI, Union Democratic Processes, in AFL-CIO Codes of ETHICAL Practices 41-45 (1957). 
stand for and hold office, subject only to fair qualifications uniformly imposed, (d) to voice his views as to the method in which the union's affairs should be conducted."116

Subsequent sections of this Code deal with these questions in a more specific manner. ${ }^{117}$ Although it is impossible to say what impact the Code will have upon democracy within the unions affiliated with the AFL-CIO, any positive effect is bound to be favorable. Moreover, the Code may be of importance, or at least is potentially important, in another context-judicial review of internal union proceedings.

One of the principal problems confronting courts reviewing internal union proceedings is, as has already been suggested, the unavailability of standards by which to judge the propriety of union performance. Courts begin with the union constitution and often go no further, for once beyond the constitution they are left with only such vague guides as "natural justice" or "public policy."118 This AFL-CIO Ethical Practices Code may well supply a standard to which the courts can properly turn, a standard which, it should be observed, fits with but a slight push into the traditional judicial approach to these problems when the union litigant is affiliated with the AFL-CIO. Two theories are possible. Under one, since unions in the federation are expected to comply with the Codes of Ethical Practices promulgated by the Committee on Ethical Practices and approved by the AFL-CIO Executive Council, ${ }^{119}$ these codes can be viewed as designed for the benefit of union members in much the same fashion as the promise in a third-party beneficiary contract is for the benefit of one intended to be the recipient of its performance. ${ }^{120}$ Under the other, because a union affiliated with the AFL-CIO is expected to change its rules if they are contrary to the standards established by the Ethical Practices Code, ${ }^{121}$ a union which fails to amend its rules and remains in the federation may be presumed to have found its rules in compliance with the Code. This presumption would enable a court to view the "contract" between the union and its members as incorporating the federation's Code. The chief merit of either approach is that standards to which the union must conform are supplied by organized labor itself.

The courts have given no indication that they are about to adopt either theory. On the other hand, there is no reason to suspect that either will be rejected if argued, especially since an increasing concern for the individual can be detected in the judicial handling of internal union problems. ${ }^{\mathbf{1 2 2}}$

116. Id. at 43 .

117. Id. at $43-45$.

118. See notes 100-04 supra and accompanying text.

119. See AFL-CIO Resolution on Ethical Practices, in AFL-CIO Codes of ExHICAI Practices 7 (1957); Code VI, Union Democratic Processes, in id. at 43.

120. See 4 Corbin, Contracts $\$ \$ 772-81$ (1951).

121. 'Code VI, § 12, Union Democratic Processes, in AFL-CIO Codes of Ethical PRACTICES 45 (1957).

122. See, e.g., Madden v. Atkins, 4 N.Y.2d 283, 151 N.E.2d 73 (1958). 
Be that as it may, it seems clear that the federal government's obligation to the worker, governed by the majority-rule doctrine, remains substantially unsatisfied by these encouraging activities of as yet unknown consequence within the union movement. These activities may mean, however, that the federal government should wait before it acts. Much can be said for keeping union government as independent of federal or state regulation as possible. One of the more sophisticated observers of these problems, Clark Kerr, has recently suggested the importance to a democratic society of plural centers of power, and the importance to this concept of independent unions. ${ }^{123}$ But he and most other disinterested and enlightened commentators agree that limited regulation of union government-whether state or federal-is not incompatible with the goal of plural power centers and may be necessary to protect the individual. ${ }^{124}$ Indeed, as has been noted, the states are engaged in regulating discipline, elections and to some extent admission policies, as well as other internal union practices. ${ }^{125}$ In all probability, no matter what the union movement does, some regulation in these areas will continue to be necessary.

The case for intelligent federal legislation in the fields of admission, discipline and election thus seems complete. Other factors, however, tend to undermine the desirability of such federal action.

\section{Federalism and Labor Union Government}

As a matter of constitutional law, power unquestionably resides in Congress to legislate on admission, discipline and elections. ${ }^{126}$ The commerce clause reaches these areas as surely as it does the regulation of collective bargaining. There is little question that Congress manifested its great wisdom when it exercised its power and enacted the National Labor Relations Act. ${ }^{127}$ Collective bargaining is a subject which demands uniform treatment. The same cannot be said with any assurance, however, about the aspects of union government under present discussion.

"Uniform" has at least two connotations. One concerns a policy which must be consistent throughout the nation if it is to be successful. The word is used

123. Kerr, Unions and Union Leaders of Their Own Choosing, in Serected Readings 106, 109. See also Lipset, Trow \& Coleman, Union Democracy 411-12 (1956).

124. Kerr, supra note 123, at 117-18. See Statement of Archibald Cox, Hearings Before the Subcommittee on Union Financial and Administrative Practices and Procedures of the Senate Committee on Labor and Public Welfare, 85th Cong., 2d Sess. 362 (1958); Statement of Clyde Summers, id. at 594. See also Summers, The Usefulness of Law in Aclieving Union Democracy, 48 Aar. Econ. Rev. 44 (Supp. 1958). But cf. Dunlop, The Public Interest in Internal Affairs of Unions, 1957 A.B.A. Section OF LAB. Rel. LAW 10, 16-17.

125. For a discussion and case presentation of the entire area of state regulation of internal union affairs, see The Group of Teachers and Practitioners of Labor Law, LaBor Relations and tHe LAW 851-1007 (1953).

126. Indeed, no one seems to have suggested otherwise.

127. 49 StaT. 449 (1935), as amended, 29 U.S.C. \$\$ 151-68 (1952). 
in this sense when it is said that the law of collective bargaining must be "uniform." It would not do for an employer in Michigan to have to respect the demands of his employees to bargain collectively if a similarly situated employer in Illinois were free to extract enforceable "yellow dog" contracts from his workers and to decline to bargain with anyone. Michigan might find itself with very little industry, a sure consequence of nonuniformity until Michigan employers came to realize that collective bargaining is mutually advantageous. ${ }^{128}$

The other connotation has to do with predictability and its importance to the regulated individuals and organizations. If one were to conclude that a uniform law should be applied by the courts in suits for breach of a collective bargaining agreement, one would probably have this consideration in mind ; for it can persuasively be argued that the primary rights and duties of parties to a labor contract should not be governed by two independent and possibly conflicting bodies of law. ${ }^{129} \mathrm{~A}$ choice of law issue would greatly complicate decision making by the parties and might invite dispute. In the event of litigation, if courts disagreed, this issue could induce forum shopping. This is a real problem today because section 301 of the Taft-Hartley Act ${ }^{130}$ creates a federal substantive law of labor contracts. ${ }^{131}$ If the federal law does not pre-empt that of the states-and whether it does remains uncertain -it will exist in competition with state law. ${ }^{132}$

Neither of these connotations of "uniform" properly attaches to a statement that problems of admission, expulsion and election require uniform treatment. Except for the governmental obligation flowing from the Case principle of majority rule, ${ }^{133}$ no national policy turns upon such treatment. ${ }^{134}$ The opinion has been voiced, however, that uniformity is necessary to protect unions from a multiplicity of possibly conflicting rules. ${ }^{135}$ The reasoning along this line is most persuasive when applied to the regulation of union elections, particularly the election of international officers. ${ }^{136}$ To subject an international union which

128. Even with uniform law, the runaway shop is not unknown. The case of Jacob H. Klotz, 13 N.L.R.B. 746 (1939), tells a story of a flight from New York City in the early days of the act.

129. See McCarroll v. Los Angeles County Dist. Council of Carpenters, 49 Cal. 2d 47, 61-63, 315 P.2d 322, 329-30 (1957).

130. 61 Stat. 156 (1947), 29 U.S.C. \& 185 (1952).

131. Textile Workers Union v. Lincoln Mills, 353 U.S. 448 (1957) ; General Elec. Co. v. Local 205, United Elec. Workers, 353 U.S. 547 (1957) ; Goodall-Sanford, Inc. v. Local 1802, United Textile Workers, AFL, 353 U.S. 550 (1957).

132. Compare McCarroll v. Los Angeles County Dist. Council of Carpenters, $49 \mathrm{Cal}$. 2d 47, 315 P.2d 322 (1957), writh Associated Tel. Co. v. Communications Workers, CIO, 114 F. Supp. 334 (S.D. Cal. 1953).

133. See text at notes 25-39 supra.

134. But see Cox, The Role of Law in Preserving Union Democracy 33 (unpublished paper; copy on file in Yale Law School Library 1958). See also text at note 142 infra.

135. See S. Rep. No. 1684, 85th Cong., 2d Sess. 4, 12, 13 (1958).

136. "There is a great need for uniformity in the laws governing union elections. International and national unions operate in many States. It would be confusing, unduly 
operates throughout the country to the laws of the several states would lead to intolerable confusion within the union-so the argument runs-were the union to attempt good faith compliance with all the requirements of fortyeight or more laws. Furthermore, the member who wished to challenge an election would have the entire country in which to shop for a favorable forum. But reported cases lend no support to this concern. ${ }^{137}$ Should the problem arise, there is no reason to suspect that conflict of laws doctrine is too impoverished to resolve the difficulties. The law of the jurisdiction in which a given international union has its headquarters would seem a likely choice for the source of applicable law. ${ }^{138}$ Although the conflicts rule might take a little time to work itself pure, this sort of problem is an ancient one in our law. Concern about it in this area almost before the problem arises seems strange indeed. ${ }^{130}$

burdensome, and often impossible for them to comply with a variety of election laws. The same considerations apply, with somewhat lesser force, to local unions, a considerable number of which function in several States. Also, the burden of checking compliance is likely to fall upon the international union." Id. at 13.

This report accompanied S. 3974, 85th Cong., 2d Sess. (1958), providing for federal election law, which was passed by the Senate, see 104 Cong. REc. 10381 (daily ed. June 17, 1958). An argument can certainly be made that, if federal legislation is necessary, it should occupy the field to the exclusion of state election laws. But the above quoted portion of the report, though ostensibly directed at the question of pre-emption, seems more fundamentally concerned with the primary issue of whether there should be any federal election legislation at all. The remaining sentences of the quoted paragraph make this clearer: "It is easier to enforce one uniform rule than a crazy quilt of State legislation and court decisions. Ill-considered State laws would interfere with the national labor policy. Too stringent laws would handicap unions in dealing with employers. Too frequent elections may keep a union in a state of turmoil." S. REP. No. 1684, 85th Cong., 2d Sess. 13 (1958). For an examination of these latter considerations, see text at notes 141-50 infra.

137. The Teamsters litigation-Cunningham v. International Brotherhood of Teamsters, 40 L.R.R.M. 2650 (D.D.C.) (preliminary injunction preventing election of officers granted), injunction stayed, International Brotherhood of Teamsters v. Cunningham, 40 L.R.R.M, 2653 (D.C. Cir.), aff'd sub mom. Cunningham v. English, 78 Sup. Ct. 3 (1957); Cunningham v. English, 40 L.R.R.M. 2693 (D.D.C.) (temporary restraining order prohibiting elected officials from assuming office), preliminary injunction issued, 41 L.R.R.M. 2022 (D.D.C. 1957) -and Ford v. Curran, 36 L.R.R.M. 2407 (N.Y. Sup. Ct. 1955), seem to be the only reported cases in which an election of international union officers was challenged. Both, but particularly the Teamsters cases, have many difficulties, none of which are connoted by either meaning of the word "uniform."

138. The several decisions cited note 137 supra do not consider the choice of law question. If unions were incorporated, the applicable law would be that of the place of incorporation. See Restatemrent, Conflict of Laws $\S 183$ (1934). See also $i d$. at $\S 342$ (obligations of partners as between themselves determined by law of the place where agreement of partnership made). The international union's headquarters as the appropriate state for choice of law purposes is undoubtedly a somewhat arbitrary selection. But the resolution of such questions in a definite manner always involves an element of arbitrariness. Since, however, the state where the union has its headquarters will probably have the largest interest in the dispute, application of its law would seem least capricious.

139. Should conflicts difficulties arise, an international union might fully protect itself by complying with the law of the state which was most restrictive, that is, the state law which attempted-perhaps too vigorously-to compel frequent and fair elections. 
If the experience yet to come ultimately indicates that the conflict of laws difficulty cannot easily be resolved, or if for some other reason now unforeseen, federal law should be needed, then, of course, we must have it. But that is not today's problem, and today there is no reason to suspect that it will be tomorrow's.

Accommodation by a union to diverse state laws on questions of local elections, disciplinary proceedings and admissions present even less difficulty. These are problems in which only a single state is likely to have any large interest. Most locals are situated in one state-the state where the employee works. In almost any situation, therefore, under the conflicts rule of almost any jurisdiction, the state law which will apply to the primary rights and duties of the parties may be forecast with great certainty. ${ }^{140}$ To be sure, an occasional case may present difficulties. One can easily pose nice problems. But the probability of difficulty is too remote to require attention at this time.

Another line of argument not unrelated to uniformity is sometimes advanced in support of the contention that federal legislation is necessary. It is simply that present state regulation is unsatisfactory, and that new state legislation may be unwise. ${ }^{141}$ If this argument is carried to its extreme, and the view taken that states are likely to behave in an altogether irresponsible fashion, the position that the national labor policy of collective bargaining requires uniform federal regulation of union democracy becomes more plausible. State law could be so restrictive as to injure the collective bargaining function of the regulated union. ${ }^{142}$ The weakness of this argument is that such state legislation would probably be invalid under the supremacy clause of the Constitution and present federal law. The Supreme Court has consistently held that states may not interfere with the rights of self-organization and collective bargaining given employees by section seven of the National Labor Relations Act. ${ }^{143}$

Quite apart from the uniformity problem, however, there is an immediate and often substantial appeal in the straightforward suggestion that we need federal regulation because state law is not all it might be now and may not be all it should be tomorrow. The short answer for purposes of this Article is to invoke a limitation enunciated at the outset and to suggest that this is beyond the present scope of inquiry. ${ }^{144}$ The suggestion assumes that political pressures will result in wise federal legislation and in unwise state legislation. Nevertheless, a longer answer to this argument is possible, one which questions the political assumption only collaterally although that assumption is

140. Although the case law is extensive, choice of law problems do not appear, suggesting, perhaps, that it is not much of a problem.

141. See S. Rep. No. 1684, 85th Cong., 2d Sess. 13 (1958) : "Ill-considered State laws would interfere with the national labor policy. Too stringent laws would handicap unions in dealing with employers. Too frequent elections may keep a union in a state of turmoil."

142. Ibid.

143. See, e.g., Hill v. Florida ex rel. Watson, 325 U.S. 538 (1945).

144. See text at note 12 supra. 
hardly beyond direct attack. ${ }^{145}$ This answer may be worth stating without detailed development.

Argument grounded in the judgment that state labor law is likely to be unwise manifests more than anything else an impatience with the federal system and a lack of skepticism which, if present, might find some comfort in that ancient institution. Two basic justifications for a federal system are found in the phrases "fractionation of power" and "the need for experimentation." If these are slogans without substance, then, of course, federal law should enter the area under discussion and every important area in which law has a role to play. If these phrases are rooted in reason as well as tradition, they tend to support a contrary conclusion. They introduce into the decision-making process two new considerations which may outweigh the judgment that federal action is needed to ensure wiser labor legislation. Indeed, the experimentation point, if valid, in fact suggests that one should not always be dogmatic about the social desirability of particular legislation, especially in a developing area of law.

"Fractionation of power" assumes that the individual in a democratic society will be freer in the long run if power in that society is diversified. ${ }^{146}$ If

145. The superiority over existing state law, for example, of the election provisions in S. 3974, 85th Cong., 2d Sess., tit. 3 (1958), see note 136 supra, is questionable. Section 303 of this bill would wipe out existing state law under which an individual member may institute suit when his union has failed to comply with the election procedures of the union constitution. If he can prove his case, in most jurisdictions he can obtain relief appropriate to the circumstances. See Collins v. International Alliance of Theatrical Employees, 119 N.J. Eq. 230, 182 Atl. 37 (Ch. 1935) (ordering supervised election with interim court control of union) ; Fisher v. Kempter, 25 L.R.R.M. 2189 (N.Y. Sup. Ct. 1949) (temporary injunction prohibiting installation of officers); see also Lacey v. O'Rourke, 147 F. Supp. 922 (S.D.N.Y. 1956) (same). The federal statute, though purporting to do the opposite, would seem substantially to limit protection presently available to the individual member. Under this pre-emptive legislation, all action is channeled through the Secretary of Labor, who is to investigate a member's charge and bring suit "if he finds probable cause to believe that a violation of this Act has occurred ...." $\$ 302(\mathrm{~b})$. No review of the Secretary's decision is provided for in the statute. Under $\$ 302(\mathrm{a})$, moreover, a "challenged election shall be presumed valid pending a final decision thereon .... and in the interim the affairs of the organization shall be conducted by the officers elected . ..." This requirement would seem to limit the court's flexibility in fashioning a decree. Thus, were the Secretary to deem the institution of suit appropriate, both lapse of time and the statutory presumption might limit the court's ability to grant full relief.

The Senate's "superior wisdom" is further demonstrated by $\S 305(a)$ of the bill, which provides :

"No person who has been convicted of any felony shall serve as an officer, director, trustee, member of any executive committee or similar governing body, business agent, manager or paid organizer of a labor organization engaged in an industry affecting commerce, prior to the restoration of his right to vote in elections held under the laws of the State of his legal residence."

146. The concept is not limited to state-federal problems; it applies to all power groups in society. The state, however, is a particularly important power center because, to some 
the federal government legislates about union democracy, it exercises its influence in a new region of societal activity. In the short run, this legislation may increase the freedom of the individual employee. ${ }^{147}$ But the states have also been excited by the disclosures of the McClellan Committee. ${ }^{148}$ Fear of future state action probably springs from a belief that states will go too far in protecting the individual rather than not far enough, with resulting injury to unions. ${ }^{149}$ A partial answer to this concern has been noted. The supremacy clause, together with section seven of the National Labor Relations Act, largely prohibits the states from interfering with unions as collective bargaining agents. ${ }^{150}$ A second answer recalls the virtues of experimentation in this area. No one really knows how far we can or should go in attempting to legislate union democracy.

These several considerations of federalism, however, should not alone suffice to deter congressional legislation in the fields of admission, discipline and election, if such legislation can substantially discharge the government's obligation to the individual employee as imposed by the majority-rule principle of Case. Unfortunately, it cannot.

\section{Minority Interests and Majority Power}

Suppose Steele and the other Negro firemen had been members of the Brotherhood-outnumbered, to be sure, by the white members. Is it likely that people with the mentality which drew the invidious color distinction when Steele was outside would have behaved differently if Steele had been inside and had protested? Perhaps; but not very likely. Would not the results probably have been the same even if the Negro firemen had had full admission, discipline and election rights within the Brotherhood?

When the $A$ company acquired the $B$ company and the union negotiated an

degree at least, it is itself democratic and, accordingly, representative. "Fractionation of power," in its broadest outlines, is summarized with special reference to labor unions in Lipset, Trow \& Colemin, Union Democracy 411 (1956): "The emphasis in this book on the undemocratic character of most labor unions is not designed to negate the general proposition of the political pluralists that trade unions, like many other internally oligarchic organizations, serve to sustain political democracy in the larger society. As many political observers have made clear, many internally dictatorial organizations operate to protect the interests of their members by checking the encroachments of other groups. Democracy in large measure rests on the fact that no one group is able to secure such a basis of power and command over the total allegiance of a majority of the population that it can effectively suppress or deny the claims of groups it opposes."

147. See text following note 112 supra.

148. In New York, in September 1957, Governor Harriman named a committee, with Professor Clyde Summers as chairman, to inquire into similar problems and to make recommendations for state legislation. The committee issued its first interim report on February 11th. Governor's Committee on IMIPRoper Labor and Managearent Practices, INTERIMT REPORT (1958).

149. See note 141 supra.

150. See note 143 supra and accompanying text. 
agreement which treated the $B$ employees as new help for purposes of seniority, would it have made any difference if the old $B$ employees had been members of the union at the time of the negotiations? In the famous Trailmobile case, it certainly would have made no difference. And the union was one generally regarded as responsible and fair. ${ }^{151}$

Jemings $v$. Jennings ${ }^{152}$ is a notorious case in which open membership and democratic procedures did not prevent the union from negotiating an agreement unfair to a nonracial minority group. Distribution of accrued wages was the issue in that case. The minority seems to have been entitled to most of the money. It went mostly to the majority.

The point of this discussion is not to suggest that the likelihood of fair representation by the majority union does not increase when the employee has an opportunity to communicate his economic needs through a democratic political process within the union. The point is much more modest, merely that the existence of an open union, fair discipline and free elections, in combination with the present Steele doctrine, is not enough substantially to discharge the federal government's obligation to individual employees. When this fact is added to the considerations of federalism sketched earlier, the wisdom of federal legislation in the admission, discipline and election fields becomes doubtful. The case against federal intrusion into these areas would be complete if one could find a better way to discharge the federal obligation which at the same time more fully respected the role of the states.

\section{Fair REpresentation}

The quest for an alternative to federal regulation of union admission, discipline and election policies is best begun at the point where the very real federal interest in these questions was first discerned. The Steele doctrine represents an attempt by the courts to discharge the government's obligation to the individual employee living within a system governed by the majority-rule principle of collective bargaining. A duty of fair representation is imposed upon the union; a corresponding right, which can be vindicated in the courts, is bestowed upon the individual employee. If Steele fully protected the individual, concern with problems of federal regulation of union democracy would be unnecessary; for the need to safeguard the minority employee is the principal valid reason, almost the only reason, for present national interest in internal union democracy.

Steele fails because courts, unable to find standards by which to test the fairness of economic distinctions in collective agreements, apply a heavy presumption of legality to union action. ${ }^{153}$ This is similar to the presumption of constitutionality federal courts accord to state action in the economic sphere-a presumption rooted in an altogether different relationship. ${ }^{154}$

151. See note 67 supra.

152. 91 N.E.2d 899 (Ohio Ct. App. 1949).

153. See notes $65-77$ supra and accompanying text.

154. Ibid. 
But the fact that states and unions are very different institutions with different sources of power does not mean that this presumption of legality is itself irrational when applied by courts to union action of the type under consideration. One reason for the presumption of constitutionality is the institutional limitation of the courts. They are not equipped to pass on the wisdom of a state's economic decisions. ${ }^{155}$ Nor are they equipped to evaluate the wisdom of a union's collective bargaining judgments. ${ }^{150}$ And yet, this understandable judicial restraint, when applied to union action, leaves unsatisfied the federal obligation to the individual employee.

If the courts are not institutionally capable of discharging the government's obligations in a satisfactory fashion, why not an institution which is? This sounds deceptively easy. Can any government agency, no matter how expert, do more than pass upon the rational nature of distinctions drawn in the collective bargaining process without seriously jeopardizing the process of collective bargaining itself? The answer to the question when put in this fashion is yes. But it takes much less sensitivity to the process than was possessed by a Harry Shulman to realize just how intricate are the problems involved. ${ }^{157}$

Collective bargaining is a vital institution because it is capable of adjusting to the complicated and changing demands of modern industrial society. It can accommodate itself to all industries and firms and to the ever-shifting conditions and problems within these industries and their subdivisions. Collective bargaining matures in a given context as personal traditions become established. It demands of its participants a continuous and intimate relationship; and wherever it appears, it is unique. ${ }^{158}$ These considerations have led the disinterested experts-professional arbitrators, arbitrators who teach and teachers who arbitrate-as well as labor people, to distrust outside intrusion, particularly government intrusion. ${ }^{159}$ There can be no challenging the wisdom of this instinct. In so far as possible, collective bargaining must remain private.

The difficulty is that, when protection of the individual is at stake, excluding the public is impossible except at a very high price. The federal government can disregard its obligation to the individual employee. Or it can attempt to discharge the obligation by moving into the area of union government. Experience indicates, however, that the move will not achieve its goal,

155. See New State Ice Co. v. Liebman, 285 U.S. 262, 283-85 (1932) (dissenting opinion of Mr. Justice Brandeis).

156. See Cox, The Duty of Fair Representation, 2 VILL. L. REv. 151, 167 (1957).

157. His peroration-beautifully communicating his sensitivity-is found in Shulman, Reason, Contract, and Law in Labor Relations, 68 Harv. L. Rev. 999 (1955).

158. See, generally, Chamberlain, Collective Bargaining (1951); Cox, The Duty To Bargain in Good Faith, 71 HaRv. L. REv. 1401 (1958).

159. See, e.g., Taylor, Government Regulation of Industrial Relations (1948); Cox \& Dunlop, Regulation of Collective Bargaining by the National Labor Relations Board, 63 Harv. L. Rev. 389 (1950) ; Cox \& Dunlop, The Duty To Bargain Collectively During the Term of an Existing Agreement, 63 HARv. L. REv. 1097 (1950); Shulman, supra note 157. 
while considerations of federalism suggest that this area ought to be left to the states. Finally, the federal government can intrude a little more into the collective bargaining process-a little more because it is now and long has been a participant in that process. The NLRB has the power, which it exercises, to regulate collective bargaining procedures and to help determine the substantive matters discussed at the bargaining table. ${ }^{160}$ If the Board were invested with the power to review the merits of union decisions in this area, the intrusion would admittedly be more extensive than ever before. The Board for the first time would be concerned, although in a limited way, with the substantive validity of collective bargaining decisions. But if the standards applied were fashioned with wisdom, the consequences to the institution of collective bargaining would be acceptable.

The task of formulating and applying standards is not easy. Neither was the job of the NLRB in the mid-thirties. The Board had to make sense out of the unfair labor practice provisions ${ }^{101}$ and out of the representation provisions of the Wagner Act. ${ }^{162}$ Responsibility for establishing the appropriate bargaining unit and for infusing meaning into the requirement of the duty to bargain forced the Board into a continuing examination of collective bargaining practices. ${ }^{163}$ If the Board-and because of this experience it seems to be the proper agency ${ }^{164}$ - were to review union decisions claimed to be violations of the duty of fair representation, the scope of this examination would have to be expanded. For the standards to be applied in such cases should come from collective bargaining practices.

These practices, or more accurately, the union's practice of collective bargaining, in part reflects the expectations of employees. In turn the employees'

160. See NLRB v. Wooster Div. of Borg-Warner Corp., 356 U.S. 342 (1958) ; Inland Steel Co. v. NLRB, 170 F.2d 247 (7th Cir. 1948), cert. detried, 336 U.S. 960 (1949); NLRB v. J. H. Allison \& Co., 165 F.2d 766 (6th Cir. 1948) ; Truitt Mfg. Co., 110 N.L.R.B. 856 (1954), enforcement denied, 224 F.2d 869 (4th Cir. 1955), rev'd, 351 U.S. 149 (1956); Cox, The Duty To Bargain in Good Faith, 71 HaRv. L. Rev. 1401 (1958); Cox \& Dunlop, Regulation of Collective Bargaining by the National Labor Relations Board, 63 Harv. L. REv. 389 (1950); Findling \& Colby, Regulation of Collective Bargaining by the National Labor Relations Board-Another View, 51 CoLuM. L. Rev. 170 (1951).

161. 49 Stat. 452 (1935), as amended, 29 U.S.C. $\$ 158$ (1952).

162. 49 STAT. 453 (1935), as amended, 29 U.S.C. $\$ 159$ (1952).

163. See authorities cited note 160 supra.

164. The NLRB should perform this function for unions regulated by the Railway Labor Act, as well as for those now subject to the National Labor Relations Act.

The FCC, the CAB, and to a much lesser extent, the ICC, get involved in seniority problems growing out of mergers, consolidations and similar transactions in the transportation and communication industries. The FCC and the $\mathrm{CAB}$ have taken an active role in resolving such disputes. See, e.g., Kent v. CAB, 204 F.2d 263 (2d Cir.), cert. denied, 346 U.S. 826 (1953). See, generally, Brown, Employee Protection and the Regulation of Public Utilities: Mergers, Consolidations, and Abandonment of Facilities in the Transportation Industry, 63 Yale L.J. 445 (1954); Kahn, Seniority Problems in Business Mergers, 8 IND. \& LAB. REL. REv. 360, 365-71. (1955). A general vesting of jurisdiction in the NLRB, as suggested in text, ought not to interfere with these agencies. 
expectations are created by past practices. ${ }^{165}$ Each employee has expectations. $\mathrm{He}$ anticipates from his own experience and the experience of others that the union, if it is doing its job will, when representing him in the negotiation and administration of the agreement, treat him in a particular way or ways vis-avis other employees in the unit. Since a particular employee may be unreasonable, single expectations are not in themselves important in creating standards. There is, however, a sense of the employee community on these questions which institutionally is reasonable. This "employee-community expectation," to coin what is perhaps an infelicitous phrase, is significant. Indeed, might not the Board, in a dispute between union and individual involving fair representation, fruitfully test the union's performance by just such a standard? ${ }^{106}$

To suggest a standard of this sort is one thing. Quite another is determining what the employee expectation is in a given case. But is it really asking too much? Are not most decision-making bodies expected to perform similar tasks of similar difficulty? Courts are constantly trying to discover what a reasonable man in the position of plaintiff or defendant would have done or would have thought. ${ }^{167}$ Judges are generalists. When their reasonable man comes from a specialized community, they may be in trouble. Nevertheless, they are often-and sometimes unwisely-asked to go ahead. ${ }^{168}$ The Labor Board member is a specialist, or becomes one after appointment. The expectations he must ascertain under the suggested approach belong to the community with which he is especially familiar. He has all the aids necessary-a specialized bar, the use of expert testimony, official notice and a learned staff. We make too much of judging if we suggest that this task is too great.

The expectations of the employee community vary with the nature of the interest at stake. ${ }^{169}$ Back pay, for example, is of a different and higher order than position on a seniority list. Seniority is important, but the expectation is not that seniority is immutable. A right to back wages would probably be so considered. The extent of reliance as well as the nature of the interest is an important related factor which influences the intensity of the expectation. The union in bargaining for seniority in the first collective agreement would have more freedom than in bargaining for discriminatory changes of status after a system of seniority had been established.

If the suggested approach were employed in the situation where company $A$ acquired company $B$, and the $B$ employees were treated as new employees

165. Indeed, in part, employees choose to be represented by a union because of expectations based upon past performance.

166. Compare the language and tone of the opinion in Ford Motor Co. v. Huffman, 345 U.S. 330, 338-43 (1953).

167. See, e.g., New York Trust Co. v. Island Oil \& Transp. Corp., 34 F.2d 655 (2d Cir. 1929) (contract); Gulf Refining Co. v. Williams, 183 Miss. 723, 185 So. 234 (1938) (tort).

168. Cf. Bickel \& Wellington, Legislative Purpose and the Judicial Process: The Lincoln Mills Case, 71 HARv. L. REv. 1, 22-25 (1957).

169. Compare Note, 65 Harv. L. Rev. 490, $495-500$ (1952). 
for the purpose of seniority, the union would be in breach of duty. ${ }^{170}$ A1though position on the seniority ladder is subject to revision, bargaining for its total elimination seems clearly outside the expectation of the employee community. Some sort of dovetailing would accordingly be required to approximate community expectation. ${ }^{\mathbf{1 7 1}}$

"Employee-community expectation," while the principal standard for review, should not be the only test employed by the Board. The dynamics of industrial relations demand that the union be permitted to depart from accepted community standards. But when it does so and is called to task by an unhappy employee, it should be required to come forward and demonstrate that the departure was in good faith and for good reason.

Although increasing the scope of review has the unfortunate consequence of putting the government more prominently into collective bargaining, it can benefit that institution as well as discharge the government's obligation to the individual employee. A good deal of controversy in the literature concerns the extent to which the union should have complete control over the processing of grievances, arbitration and litigation under the labor contract.172 The controversy centers about protection of the individual. As an institutional matter, exclusive control by the unions would almost always seem desirable because many disputes under an agreement have implications which are much broader than the interest of the individual worker. Resolution of a dispute may thus establish a rule for the future far more important to the union than the immediate settlement is to the employee. In this sort of situation, where control is diversified, the results may be unfortunate. ${ }^{173}$ But exclusive control in the union would today leave the employee with no protection except the Steele doctrine. This is clearly not protection enough where complicated problems involving administration of the agreement are in issue. ${ }^{174}$ If the scope of review of the union's action were broadened, however, the individual might well be adequately protected, even though the union had complete charge of processing the dispute.

\section{ConcLusion}

Two considerations should impel the federal government toward choice of an expanded doctrine of fair representation rather than legislation of union democracy. First, considerations of the distribution of power in our federal system suggest that the regulation of union admission, discipline and election be left to the states. And second, federal legislation in these areas would fall

170. See text at notes 67,151 supra.

171. See Kahn, supra note 164, at 371-78; cf. Cox, The Duty of Fair Representation, 2 VIL. L. REV. 151, 163 (1957).

172. Compare Cox, Rights Under a Labor Agreement, 69 HARv. L. REv. 601 (1956), with Report of Committee on Improvement of Administration of Union-Employer Contracts, 1954, Individual Grievances, 50 Nw. U.L. REv. 143 (1955).

173. See Cox, Rights Under a Labor Argeement, 69 HARv. L. Rev. 601 (1956).

174. See text at notes 50-58 supra. 
short of the mark. Discharge of the duty to the individual may better be accomplished by reviewing union action than by attempting to influence its action through protection of the member's participation within the union. The unfortunate truth is not only that members do not always participate in their union, but that fully protected participation does not always safeguard the minority from majority abuse.

These two conclusions, however, cannot obscure the fact that an expanded doctrine of fair representation must be accompanied by a regrettable increase in government control of collective bargaining. The alternative is to ignore individual rights; and this is no real alternative at all. 